\title{
Institutional Design and Performance of Markets for Watershed Ecosystem Services: A Systematic Literature Review
}

\author{
Hao Wang *, Sander Meijerink and Erwin van der Krabben \\ Institute for Management Research, Radboud University, 6525 AJ Nijmegen, The Netherlands; \\ s.meijerink@fm.ru.nl (S.M.); e.vanderkrabben@fm.ru.nl (E.v.d.K.) \\ * Correspondence: h.wang@fm.ru.nl
}

Received: 18 June 2020; Accepted: 5 August 2020; Published: 7 August 2020

check for updates

\begin{abstract}
Markets for watershed ecosystem services have been developed as a tool in integrated water resources management. The development of vast markets for watershed ecosystem services has raised attention for the performance of these markets, their institutional design, and how their institutional design influences market performance. The main research questions guiding this systematic literature review are: Which types of markets can be distinguished; how is market performance operationalized; which institutional design characteristics are distinguished in the literature; and which of these characteristics are crucial to understanding performance? A systematic review of 224 journal articles from Web of Science leads to several main findings regarding these questions. Market performance is usually equated with effectiveness in the reviewed articles. Discussions in these articles include whether the market contributes to the preservation of ecosystem services, what the distributional impacts are, and what the participation rate is. The reviewed articles have illustrated specific institutional design features as well. The key features include the security of property rights, role of governments, bundling of ecosystem services (ES), and role of trust. In those articles addressing the relationship between institutional design and performance, the relevance of monitoring and enforcement, clearly defined property rights, and geographical market scope have been pointed out.
\end{abstract}

Keywords: institutional design; performance; ecosystem services; market; systematic literature review

\section{Introduction}

A watershed is an area of land that drains into a common water source [1]. Pressures, such as population growth, socio-economic development, and climate change, result in a declining state of watershed ecosystems. The degradation calls for management embracing proper integration of ecological and socio-economic factors. The concept of ecosystem services, expressing the benefits that people obtain from ecosystems [2], potentially is an effective bridge between ecological and economic approaches [3]. Ongoing studies in theory and practice add to the incorporation of this concept into markets and payment schemes [4].

The implementation of a market for watershed ecosystem services can be an alternative that reaches a variety of goals with respect to watershed protection or restoration, such as increasing water flows and improving water quality [5]. Even though various market schemes have been rapidly designed and implemented, many of them are still at the early stage of development, and some are falling short. Examining how they are functioning and what barriers they are facing could provide theoretical guidance to the future implementation of markets for watershed ecosystem services.

Such emerging markets might face socio-economic, environmental, technological, and infrastructural barriers, as well as institutional barriers. In this paper, we will focus on institutional 
barriers and institutional design specifically, together with their impact on the functioning of markets for watershed ecosystem services. The three main reasons for this are: (1) that in institutional-economic theory, institutional factors are considered crucial to market performance; (2) that institutional factors are more amenable to change than, for example, socio-economic factors; and (3) that many of these watershed ecosystems markets are emerging and still immature, and they may therefore particularly benefit from institutional changes.

There is an emerging body of international literature on the relationship between institutional design and the performance of markets for watershed ecosystem services. It provides an opportunity to draw lessons about approaches to assess their outcomes and to achieve better outcomes. This raises our research topic, namely a systematic literature review with regard to the relationship between the institutional design of markets for watershed ecosystem services and their performance. Thus, the paper aims, on the one hand, to provide an overview of articles that have analyzed and discussed this relationship regarding watershed ecosystem services and, on the other hand, to draw lessons on how institutional barriers prevent desired outcomes from markets for watershed ecosystem services and how institutional design may help to improve market performance.

The overview and lessons can be useful as a reference to researchers as well as practitioners in the field of markets for watershed ecosystem services. Researchers might use this as a starting point to conduct further research. It might be interesting to assess existing markets regarding a certain performance criterion, test a relationship between institutional design and performance in a different context, or explore more relationships that have not been concluded by the previous research. Practitioners might take these lessons from previous research into account when they are designing a potential market, or adjusting current market design.

To address this topic, more details need to be explored about the key concepts, institutional design and performance. In addition, there might be differences between different types of markets in their institutional design and performance. Thus, three more questions need to be studied in this literature review: Which types of markets for watershed ecosystem services can be distinguished; how can the performance of these markets be measured; and what are the institutional design characteristics of these markets?

The paper is structured in five main parts. Part two presents the theoretical framework we use to analyze the relevant literature. Part three proceeds by presenting the methodology, including the procedure to define sample articles and key points to focus on when screening full texts. Part four presents the review results and analysis in the context of our framework. In light of this systematic review, we draw our conclusions in part five.

\section{Framework for Systematic Review}

\subsection{Concept and Scope of (Markets for) Watershed Ecosystem Services}

"Watershed ecosystem services" refer to the ecosystem services provided by a watershed [1], which can include all types of ecosystem services, restricted as such by the geographical character of the services. We are aware that all the ecosystem services can be directly or indirectly linked to water. In this review, we focus on the watershed ecosystem services that are explicitly defined with "water" or "aquatic". To indicate the typology, we refer to the Common International Classification of Ecosystem Services (CICES) version 5.1 [6], which has the hierarchical structure of section, division, group, class, and class types. This structure is designed for users to go to the most appropriate level of detail required by their applications [7]. The structure of the first four levels is sufficient for this review to distinguish the ecosystem services traded in the markets, as shown in Table 1. 
Table 1. Watershed ecosystem services that we focus on.

\begin{tabular}{|c|c|c|c|}
\hline Section & Division & Group & Class \\
\hline Provisioning (Abiotic) & Water & Surface water used for nutrition, materials, or energy & Surface water for drinking \\
\hline Provisioning (Abiotic) & Water & Surface water used for nutrition, materials, or energy & Surface water used as a material (non-drinking purposes) \\
\hline Provisioning (Abiotic) & Water & Surface water used for nutrition, materials, or energy & Freshwater surface water used as an energy source \\
\hline Provisioning (Abiotic) & Water & Ground water for used for nutrition, materials, or energy & Ground (and subsurface) water for drinking \\
\hline Provisioning (Abiotic) & Water & Ground water for used for nutrition, materials, or energy & $\begin{array}{c}\text { Ground water (and subsurface) used as a material } \\
\text { (non-drinking purposes) }\end{array}$ \\
\hline Provisioning (Abiotic) & Water & Ground water for used for nutrition, materials, or energy & Ground water (and subsurface) used as an energy source \\
\hline Provisioning (Abiotic) & Water & Other aqueous ecosystem outputs & Other \\
\hline Regulation and Maintenance (Biotic) & $\begin{array}{l}\text { Transformation of biochemical or } \\
\text { physical inputs to ecosystems }\end{array}$ & $\begin{array}{c}\text { Mediation of wastes or toxic substances of anthropogenic } \\
\text { origin by living processes }\end{array}$ & $\begin{array}{l}\text { Bio-remediation by micro-organisms, algae, plants, } \\
\text { and animals }\end{array}$ \\
\hline Regulation and Maintenance (Biotic) & $\begin{array}{l}\text { Transformation of biochemical or } \\
\text { physical inputs to ecosystems }\end{array}$ & $\begin{array}{c}\text { Mediation of wastes or toxic substances of anthropogenic } \\
\text { origin by living processes }\end{array}$ & $\begin{array}{l}\text { Filtration/sequestration/storage/accumulation by } \\
\text { micro-organisms, algae, plants, and animals }\end{array}$ \\
\hline
\end{tabular}


In the literature, both broader and narrow definitions of markets for ecosystem services exist. The broader definition refers to any transaction where financial, or sometimes in-kind, compensation is made for providers of an ecosystem service [8]. These transactions can involve government or private sectors, and can be market-driven or government-guided. The narrow definitions distinguish government-led payment schemes from markets (see e.g., [9]). Considering the fact that present market-driven approaches almost always involve varying degrees of government involvement, which means the "pure market" (see e.g., [10]) without any interaction of government is rare, we will apply the broader definition for this review. This means we will use "markets for ecosystem services" as a generic term to refer to a wide range of economic schemes that take the ecosystem services we indicated above as commodities, including Payment for Ecosystem Services (PES), Payment for Watershed Ecosystem Services (PWS), cap-and-trade permits, certification schemes, and others.

This paper takes ecosystem services (ES) markets for granted. We are aware that there are also many critics on accounting and monetizing ecosystem services, for example, because the commodification of these services fails to address the intrinsic value of ecosystems ([11,12]). Although we recognize these limitations, markets for ecosystem services have evolved, and it is interesting to learn more about the various ways in which performance is defined, and how their institutional design may be changed to improve (certain dimensions of) market performance.

\subsection{Institutional Design and Market Performance}

Usually, the work of Ronald Coase on property rights and transaction costs is viewed as a central inspiration for the field of New Institutional Economics. Coase [13] argued-which later became famously known as the Coase Theorem - that when rights are well defined and the cost of transacting is zero, resource allocation is efficient and independent of the pattern of ownership. In reality, however (and Coase was fully aware of that), the assignment of property rights is not clear and transaction costs are almost never zero. In line with that, Lai and Hung [14] explain: "where transaction cost is not zero or property rights are unclear or poorly defined, the assignment of rights and liabilities would affect resource allocation" [14]; and "... certain resource allocation would increase (decrease) efficiency by reducing (increasing) transaction costs" [14]. Thus, the Coase Theorem draws our attention to the impact of institutional design on the performance of markets.

In Lai and Hung's [14] work, seven categories of frequently used resource allocation outcomes in empirical planning and real estate research are identified, namely input prices, input quantities, output prices, output quantities, quality of input, quality of output, and externalities. However, in the literature we reviewed, the performance assessment of PES or other tools is rarely discussed from the above seven aspects. Many see PES as a Coasean market solution to the problems of externalities (see e.g., [15]), which is used to preserve the ecosystems that provide these services [16]. Therefore, whether a PES program achieves the objectives of improving ecosystem services is a vital perspective to examine its effectiveness [17]. Poverty alleviation is also a critical goal of some schemes, because the conservation and rural development circles have received the emerging paradigm [18], and the ecosystem services preservation and pro-poor welfare outcomes are inseparably linked [19]. Last but not least, efficiency also has drawn attention based on the fact that it can be costly to establish a market for ecosystem services (see e.g., [17]). Based on the literature, we would like to conclude the following three provisional dimensions of performance, namely, (1) preservation of ecosystem services, (2) distributional impacts, and (3) efficiency.

Following Lai and Hung [14], we refer to institutional design as the rules of the markets that make the actors certain about "assignment of rights and liabilities". They distinguish four main concepts as a further operationalization: law, governance of institutions, means of coordination, and contractual arrangements, and subsequently translate them into concrete planning terms. For instance, in their research, "law" covers regimes of planning and development permissions, planning and development conditions, planning agreements, planning standards, formal public participation counts, and impact assessment ratings [14]. To make these dimensions applicable for our review, we also extend concrete 
meanings for each concept. (1) "Law" refers to the legal documents that legalize the trading, define related property rights, or define the transaction rules; (2) "governance of institutions" refers to the roles of institutions involved in the scheme, the market scope, and market scale; (3) "coordination" refers to the interaction between different stakeholders for the markets, including governmental agencies, research institutions, and non-governmental organizations; (4) "contractual arrangements" refers to the details in contracts, including the commodities, allocation methods, buyers and sellers, payment types and levels, as well as contract durations.

With these four dimensions for institutional design and three dimensions of performance, we were able to develop a two-dimensional matrix to categorize the articles, which we included in the systematic review (Table 2).

Table 2. Provisional matrix.

\begin{tabular}{|c|c|c|c|c|c|}
\hline & & \multicolumn{4}{|c|}{ Institutional Design } \\
\hline & & Law & $\begin{array}{c}\text { Governance of } \\
\text { Institutions }\end{array}$ & $\begin{array}{c}\text { Means of } \\
\text { Coordination }\end{array}$ & $\begin{array}{c}\text { Contractual } \\
\text { Arrangements }\end{array}$ \\
\hline Performance & $\begin{array}{c}\text { Preservation of ecosystem services } \\
\text { Distributional impacts } \\
\text { Efficiency }\end{array}$ & & & & \\
\hline
\end{tabular}

The above leads to the following framework for a systematic review of the literature (Figure 1). Through this framework, we intend to indicate that different types of markets for watershed ecosystem services exist, while institutional design influences the performance of these markets. In turn, market performance will give feedback for their institutional design. Moreover, different types of markets may have different institutional design principles, different performance criteria, and different relationships between institutional design and performance.

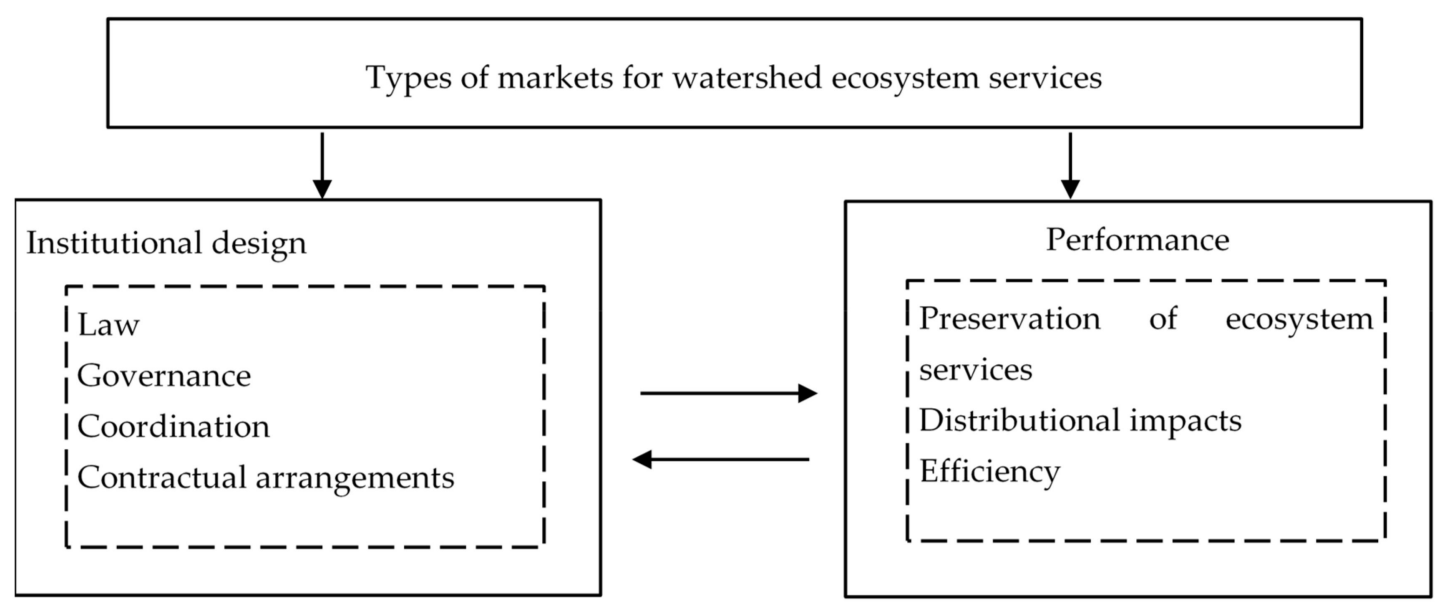

Figure 1. Framework to assess the articles.

\section{Methodology}

Following bibliometrics literature [20] and using various systematic reviews as a guideline [14,21-23], our sequential process to the systematic review proceeded from query formulation to full text analysis, which fits the PRISMA diagram [24] (Figure 2). 


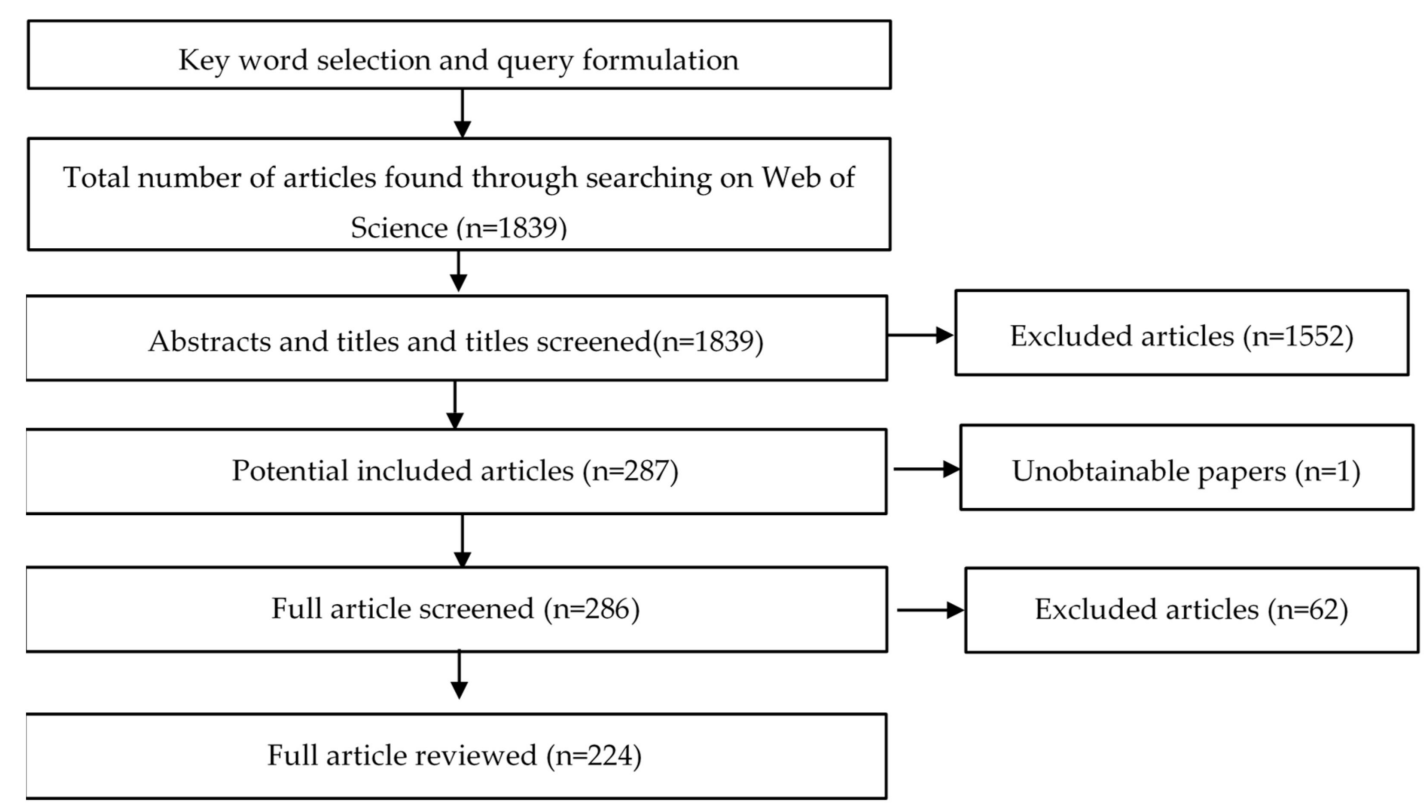

Figure 2. Steps in defining articles for review.

We processed the query with relevant keywords on Web of Science Core Collection. This collection accesses literature from editions of Science Citation Index Expanded (SCIE, 1945-Present), Social Sciences Citation Index (SSCI, 1956-Present), Arts and Humanities Citation Index (AHCI, 1975-Present), and Emerging Sources Citation Index (ESCI, 2015-Present). Based on several rounds of trials, we made a selection and combination of keywords. To guide the search, (1) keywords corresponding to "watershed" were lake*, pond*, river*, stream*, water*, or hydro*; (2) keywords corresponding to ecosystem services were "ecosystem service" ${ }^{* \prime}$ or "environmental service*"; and (3) keywords corresponding to markets were "market", "payment", "trade", "compensation", or "trading". The use of the asterisks in these keywords was to include the records of articles containing the terms that begin with the same letters. For instance, the use of "lake" was to include terms "lake", "lakes", and "lakeside". We first approached all the 1839 results after we applied this query formulation on Web of Science for years from 1945 to 2017. Abstracts were screened to make a selection of the articles that would be included for review, considering that electronic searching might be imprecise and capture many studies that employ the same terms without sharing the same focus [20]. Abstract screening was based on the assumption that the authors mention in the abstracts if institutional or performance issues related to markets for watershed ecosystem services were analyzed and would appear in the full text.

For abstract screening, a set of inclusion criteria had been developed to select articles. Abstracts were included if they (1) discussed institutional design of the markets for watershed ecosystem services or (2) discussed performance of markets for watershed ecosystem services. This led to an exclusion of 1552 abstracts, which are (1) not in English; (2) duplications; (3) focusing on coastal areas; or (4) not on the topic, which means not on the design, or assessment of economic instruments. When screening the full articles of these 287 abstracts, the same set of inclusion criteria were also applied, which lead to an exclusion of 62 more articles.

We were able to include 224 articles in this systematic literature review. These articles include both theoretical and empirical studies with scenario analyses or case studies. In both theoretical and empirical studies, we focused on the types of markets, institutional design principles, performance criteria, and the relationship between institutional design and performance.

We would like to mention that research on ecosystem services valuation was not included in our article group, even though valuation might contribute to the pricing of ecosystem services from the perspective of value-based pricing. There is still a great deal of confusion among decision makers and 
academics from all disciplines about the validity and implications of ecosystem service valuation [25], so it is still not widely used for pricing in practice.

Even though we tried to conduct the search, collection, and selection as systematically as possible, the procedure is certainly not fully comprehensive. It is possible that some related articles were not collected because our query formulation was not able to embrace the items they used. For instance, fish market is a market for watershed ecosystem services with a rather long history, but a considerable number of articles on fish markets do not use the term "ecosystem services", so we failed to include them in our article group. In addition, as our query was carried out on the Web of Science, we missed other related unpublished research works, or articles published in journals excluded by SCIE, SSCI, $\mathrm{AHCI}$, and ESCI editions. In other cases, it appeared to be difficult to decide on the right coding and/or categorization of the articles. Keeping these limitations in mind, we can still make a fairly accurate and reliable selection of articles and thus give a reliable overview of the previous research on institutional design and performance on markets for watershed ecosystem services.

\section{Analysis}

\subsection{Basic Characteristics}

Temporal distribution. The 224 articles analyzed in our paper were published between 1994 and 2017, and more than $90 \%$ were published after the year of 2007. As shown in Figure 3, we also displayed a comparison between the temporal distributions of the 224 full articles and the original 1839 abstracts.

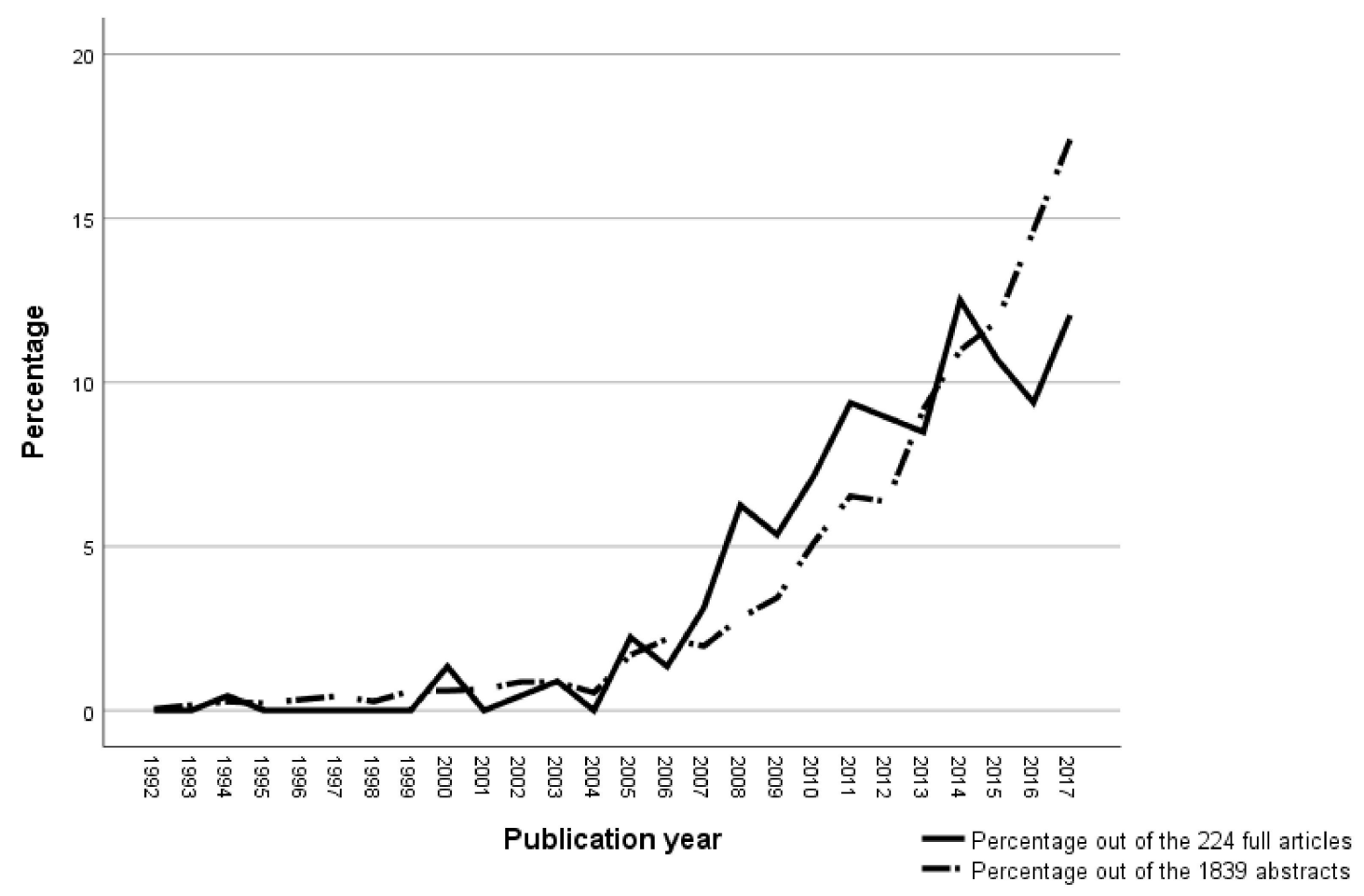

Figure 3. Temporal distribution of articles reviewed and articles searched.

Geographical distribution. This concerns geographical distributions (Geographical Regions by UNSD [26]) of both the first authors' institutions and the projects of markets for watershed ecosystem services that are studied, as shown in Figure 4. The top two regions with the highest number of publications are Northern America (41.96\%) and Western Europe (12.50\%). Within the 224 articles, 181 of them embrace empirical research. Two of them studying projects from international databases are not included in the following calculation, considering that detailed lists of the projects are not displayed. The rest 179 articles cover around 445 projects (with overlaps), including existing projects 
and potential projects. More than $50 \%$ of the projects are located in Latin America and the Caribbean and North America, followed by East Asia (14.16\%), Southeast Asia (11.24\%), Sub-Saharan Africa (4.49\%), Southern Europe (3.37\%), and Australia and New Zealand (2.92\%), Western Europe (2.25\%), South Asia (1.80\%), Northern Europe (1.35\%), and Central Asia (0.22\%). Regions of Northern Africa, Western Asia, Eastern Europe, Melanesia, Micronesia, and Polynesia are not covered.
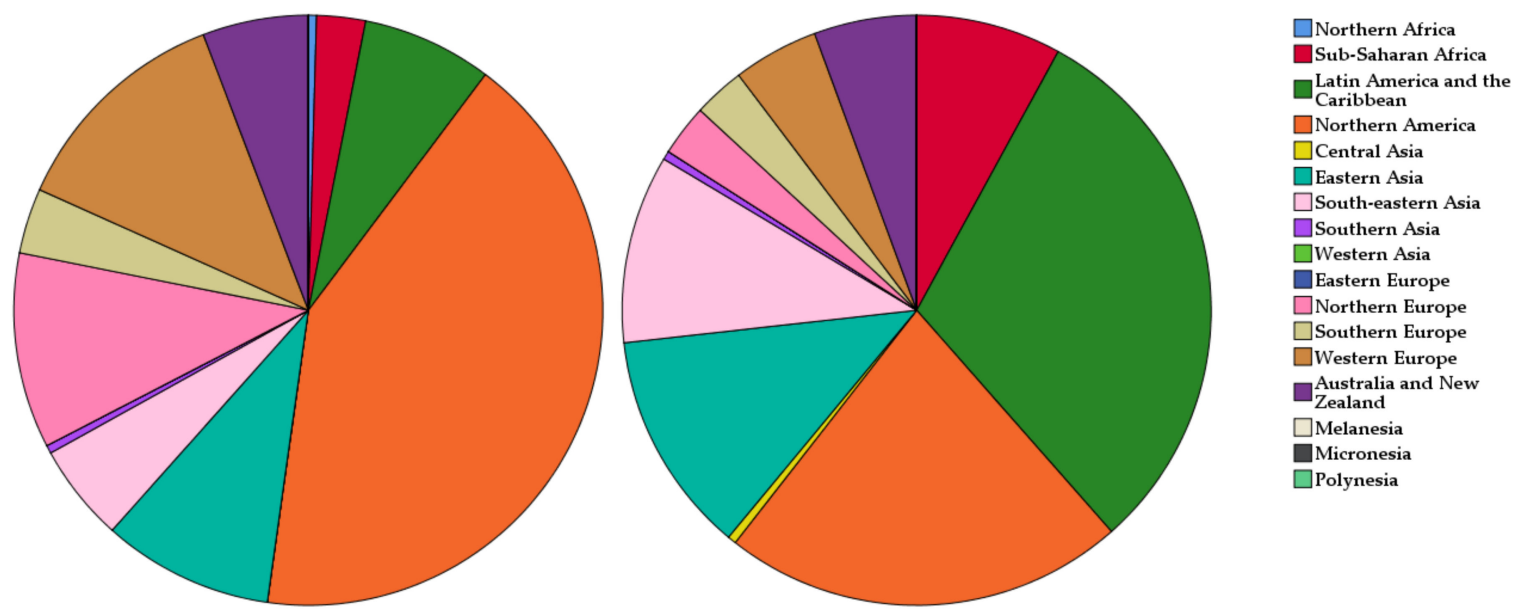

Figure 4. Left panel: geographical distribution of first authors' (first) institutions. Right panel: geographical distribution of projects studied in the reviewed articles.

Journal distribution. The articles were from 131 journals. More than $20 \%$ were published in Ecological Economics (11.61\%) and Ecosystem Services (10.27\%), followed by Land Use Policy (3.57\%), Ecology and Society (2.68\%), and Water International (2.68\%).

\subsection{Watershed Ecosystem Services and Markets}

We are aware that there is a vast discussion on the concept and typology of ecosystem services, and the literature is moving very fast [27]. The discussion includes a distinction between means and ends, or between instrumental values and terminal values, which is vital to effective decision making [28] and avoiding double counting in valuation [29]. Even the CICES typology that this paper is referring to is not yet based on a broad consensus. In the articles that we reviewed, definitions by Daily [30], Costanza et al. [31], De Groot et al. [32], Boyd and Banzhaf [33], MEA [2], and TEEB [34] are frequently cited.

Different terminology related to watershed ecosystem services is used in the literature, such as "watershed ecosystem (environmental) services", "hydrological environmental services", "freshwater ecosystem services", "water ecosystem services", "ecosystem services for water", and "ecosystem goods and services provided by healthy watersheds". These concepts are not always clearly defined, and the very same concept is sometimes defined differently. For instance, Deal et al. [35] define ecosystem services for water as water supply, water damage mitigation, and water-related cultural services, whereas others consider flow regulation as an ecosystem service as well [36].

Among the types of markets covered by the articles, payment schemes including payments for ecosystem services (PES) and payments for watershed services (PWS) are discussed most frequently. Terms in the articles that are similar to PES include payment for ecosystem (or environmental) services (PES) and reward for ecosystem services (RES); terms that are similar to PWS include payment for water (or watershed) services (PWS), payment for watershed ecosystem services (PWES), and water PES. The frequent discussions on PES and PWS might be explained by the broad scope of these two terms. In some articles, PES and PWS are not distinguished from other markets for watershed ecosystem services. For instance, research by Jack, Kousky, and Sims [37] takes PES as an overall concept that covers tradable permit systems, subsidies, and others. Huber-Stearns et al. [38] take PWS as the 
overall concept as well and classify PWS programs based on their focus on water quantity or water quality. Bennett et al. [28] identify five main types of PWS programs including source water protection programs, fire risk mitigation partnership programs, point source pollution offsets, voluntary customer offsets, and hydropower mitigation initiatives. Figure 5 provides the scope comparison of different market types regarding their broadest meanings that have been referred to in the literature. We can see a clear tendency of bundling watershed ecosystem services as a commodity in payment schemes.

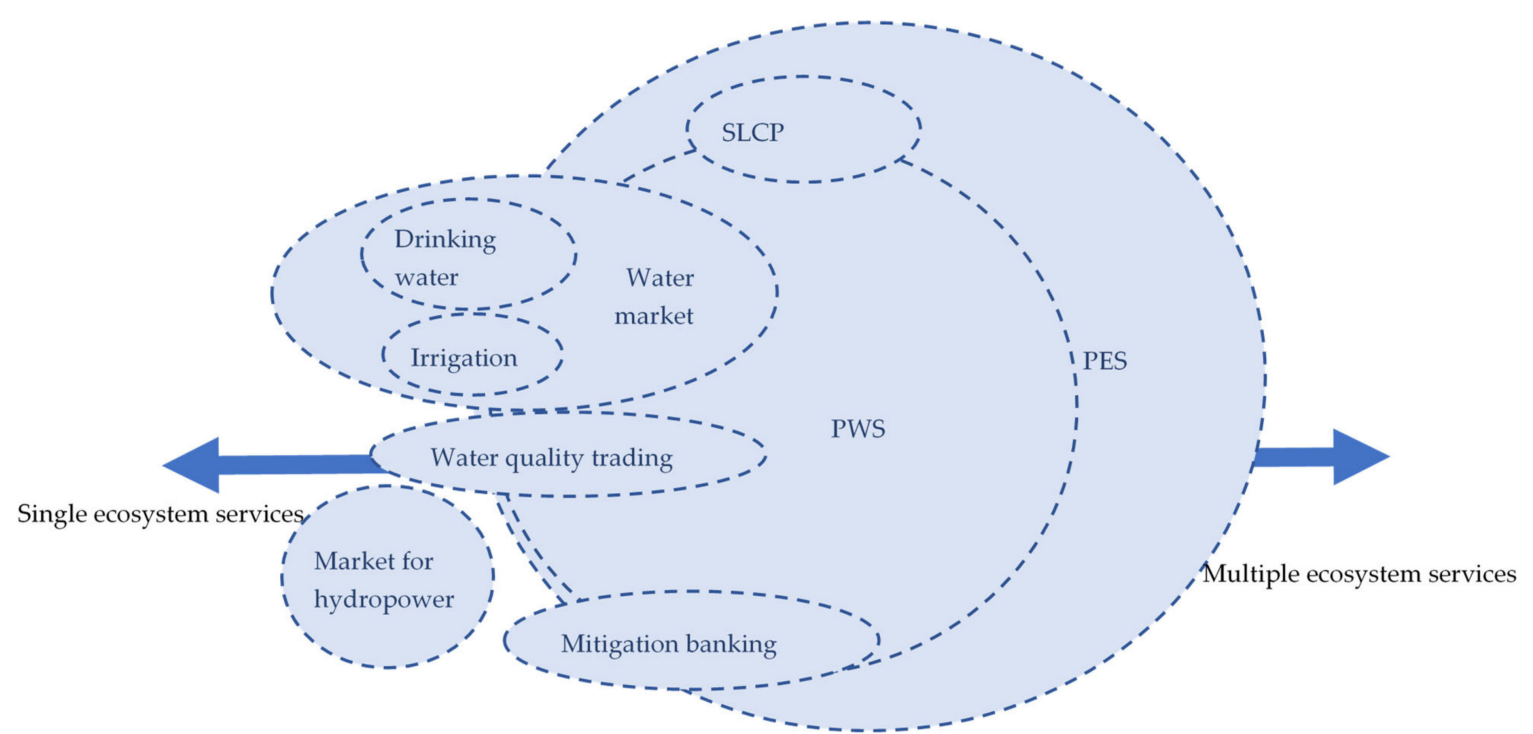

Figure 5. Scope of different markets indicated by the articles.

\subsection{Performance Criteria}

Full paper screening confirmed that the outcomes of markets of watershed ecosystem services have been rarely discussed from the perspectives of input prices, input quantities, output prices, output quantities, quality of input, quality of output, or externalities. As we had expected beforehand, important performance criteria used in the literature are (1) the contribution of the market to the preservation of ecosystem services (effectiveness), (2) distributional impacts (fairness), and (3) cost effectiveness (efficiency). A fourth frequently used performance criterion is (4) market participation (see also Table A1 in the Appendix A).

Most of the programs were initiated to preserve certain ecosystem services, which automatically become an assessment criterion. This is similar to the environmental effectiveness measured by some literature [29]. Regarding markets for watershed ecosystem services, their influence on water quality or water quantity has been widely measured. To measure this influence, it is challenging to exclude the effects of other factors such as related policies and resident activities. Hydrologic modelling has been introduced to incorporate these interaction effects [25]. However, there are still uncertainties surrounding hydrology process and model outputs, so more research and practice are necessary [25]. Other research provides evidence that some PES schemes unintentionally fail to preserve certain ecosystem services [39].

The distinctive attention on distributional impacts can partly be explained by the fact that many areas that provide considerable volumes of ecosystem services are less developed. Therefore, certain programs have been aimed at improving the livelihood of the neighbourhood, such as increasing local income (see e.g., [40]) or providing technical assistance (see e.g., [41]). For the assessment, it is necessary to distinguish the targeted group, because the schemes will not only influence the sellers, but also the buyers, as well as the neighbours who are not involved in the markets [42].

Assessment of efficiency needs vast quantitative data. However, these data are not always available. For instance, in some PWS programs, the collection of costs data was challenging [43]. 
Simulations are applied in some studies to test potential efficiency (see e.g., [44,45]); another way to assess the efficiency is to compare welfare changes before and after the establishment of a market (see e.g., [46]).

A vast group of articles on PES pay attention to participation. One of the reasons for this is that data on participation rates or participation numbers are relatively well accessible (see e.g., [47]). Participation is often related to the other performance criteria. As an example, an increase in participation rate may enhance the effectiveness of the market. Therefore, participation may also be considered an intermediary variable.

Finally, many articles provide rather general assessments of performance, claiming markets to be (or not to be) beneficial, profitable, efficient, mature, successful, or viable, but mostly without further discussions on this claim.

\subsection{Institutional Design Features}

We organized institutional design characteristics of markets according to the institutional design dimensions that we identified in our provisional matrix, namely, law, governance of institutions, means of coordination, and contractual arrangements (See Table A2 in Appendix A).

Law and policy create the basis for the institutional structure [48,49]. In many cases, markets are initiated by a national or local law prescribing the main rules of the market. Other environmental laws and policy regulations may influence foundations of the markets as well. It is crucial to integrate schemes with existing legislation, policies, and programmes [39].

Governance of institutions in our framework refers to the roles of the institutions (both governmental and non-governmental organizations) involved in the market, market scope (what services can be traded and what are the geographical limits), and market scale (size). Governmental actors play a crucial role in most markets for watershed ecosystem services, as governments are responsible for water resources management and the protection of ecological values [50].

Means of coordination issues discussed include interaction between different stakeholders in the markets, as well as coordination between different programs. Collaboration between governmental agencies, research institutions, and non-governmental organizations is argued to be critical in the development and implementation of PES programs [48].

Contractual arrangements regulate in detail what can be traded, who is allowed to buy and sell, how trading takes place, and how the prices of ecosystem services are determined. We can distinguish between markets where one type of ecosystem service is being traded from markets where a bundle of ecosystem services is being traded [35]. Payers and beneficiaries may vary from governments to private enterprises, from a community to a resident [51]. Moreover, price-setting has been investigated in various studies using as a reference price of opportunity costs, ecosystem services valuation, and hydrological flows valuation [52]. Alternatively to payment in cash, payments can also be in-kind, such as compensation provided to ES sellers through technical assistance and infrastructure works [53].

It is worth noticing that some articles have additionally discussed trust (or distrust), which can be considered an important informal institution [54]. It has been argued that trust can be built through collaboration and coordination [55-57].

The literature points to two other important institutional design features of markets for ecosystem services, namely conditionality and additionality [29,40,52,58-63]. Conditionality means that in a conventional market, sellers receive payment only if they provide the contractually agreed goods or services, and additionality indicates that credits should be granted only in response to incentives created by the program, only paying for actions that would otherwise not occur [63].

\subsection{Relationship Between Institutional Design and Performance}

Only a few of the selected articles on markets for watershed ecosystem services discuss explicitly the relationship between the institutional design and performance of these markets (See Table A3 in Appendix A). The most important findings are summarized below. 
Links between preservation of ecosystem services and different institutional design dimensions of law, governance, and contractual arrangements have been identified. Legislation that creates a legal basis [51] and capacity for water quality trading, for instance legal water quality standards, has contributed much to the effectiveness of water quality schemes [64]. On the other hand, legal uncertainty about property rights, for instance land tenure in SLCP, hampers the achievement of environmental goals [65]. These examples indicate that governmental regulation is of utmost importance to the environmental effectiveness of PWS.

The role of national government is more relevant when it leads to creating the necessary legal framework for schemes such as PWS, and if sufficient governmental institutions are present, property rights can be clearly assigned and enforced [66]. The support of the local government is also crucial to motivating local stakeholders and mobilizing finance for conservation efforts, as well as designing acceptable watershed protection [66]. Between buyers and suppliers, there exist intermediaries that bring the two together or facilitate a financial transaction between the two. The intermediaries can be national government, local NGOs, local municipalities, or international donors. Research concludes that the number of intermediaries has a significant negative effect on the likelihood that the PWS meets its environmental objectives [16]. The importance of geographical scope has also been discussed. Environmental amenities by ecosystems are generally only beneficial to relatively nearby areas. Ignoring or inadequately managing geographic limits could undermine the ecological integrity [67]. Market scale is another promising aspect. Many of the pilot and small watershed-based programs reported greater successes than larger, established regional or national programs $[35,64]$.

Regarding detailed contractual arrangements and preservation of ecosystem services, concepts of bundling and stacking ecosystem services payments can promote the integration of multiple ecological values and greater ecological benefits than a single-program or market approach [49].

When it comes to the distributional impacts of the schemes, factors related to property rights are repeatedly mentioned [68]. Awareness of institutional contexts, including property rights conflicts, can be critical to ensure the effectiveness of these activities from an equity and poverty-reduction standpoint [69]. Insecure property rights, together with factors like lack of access to credit and information and limited land holdings, are often directly correlated with poverty [70]. Markets might raise competition for control over natural assets and lead to exclusion and further marginalization of the poor [71].

Influence of market efficiency by the governance dimension of market scope has been examined in certain schemes. For instance, in a water quality tender program where participants bid with their proposals to improve water quality, it was found that, by increasing the scope of a tender via the increase of the pool of potential proposals, cost efficiencies could be realized, based on an assumption of consistent bidding behaviour [72].

In line with the attention on participation in payment schemes, the factors that might influence this performance dimension have also been examined, including law, governance, and contractual arrangements. The concern over the legal ramifications of non-compliance and the enrolment of neighbours influence the program enrolment $[69,70]$. Strong property rights also mediate access to the schemes [70], while tenure insecurity remains the most important obstacle to widespread participation in the PES program [46]. Market scale of wetland and stream compensation mitigation markets could decrease market participation when they are divided into (too) many spatially narrow trading zones [65]. Types of ecosystem services that are commodified in the markets also matter. Research concludes that landowners' preference to participate in incentive programs that encourage management to improve water yields or wildlife habitat appear to increase carbon sequestration [73].

Regarding the obstacles to general success of payment schemes, factors like 'lack of coordination between implementing agencies' [74], 'secured tenure rights' [66], and 'insufficient payments to encourage smallholders' [75] have been pointed out.

Vice versa, the performance of markets for watershed ecosystem services may also influence their institutional redesign [76]. For instance, research has shown that implementation of PWS schemes 
can contribute to the creation of new property rights [66] and provide an incentive to develop more secure property rights [77,78]. Given the importance of performance assessment, estimation models and monitoring data have also caught attention [79], which require certain research capacities in the fields of hydrology, ecology, economics, and social science [49].

Social and regional context plays an important role in successful implementation; understanding social norms, values, and existing preferences provides important information $[64,80,81]$. Together with the complexity in ecosystems, the examined relationships in some cases might be context-dependent.

\section{Conclusions}

In this paper, we wanted to learn more about the relationship between the institutional design and the performance of markets for watershed ecosystem services. The main research questions are: (1) What types of markets for watershed ecosystem services can be distinguished; (2) how can the performance of these markets be measured; (3) what are the institutional design characteristics of these markets; and (4) how does institutional design influence market performance? To answer these questions, we have made a systematic literature review and analyzed 224 articles using Lai and Hung's [14] framework on the relationship between institutional design and market performance.

Our systematic literature review reveals a broad range of markets for watershed ecosystem services. The vast majority of the literature discusses payments for (watershed) ecosystem services, which tend to trade a bundle of watershed ecosystem services in the program. Other market types mentioned in the literature are water quality trading, water markets, and mitigation banking.

The analysis of how market performance is operationalized and measured yields some interesting results. The literature focuses mainly on the contribution that these markets make to the implementation of specific policy objectives, i.e., on the effectiveness of markets. Frequently asked questions include whether the market contributes to the preservation of ecosystem services, what the distributional impacts are, and what the participation rate of the market is (especially in PES).

Dimensions of institutional design, namely law, governance of institutions, means of coordination, and contractual agreements, have been widely recognized in the literature. This review has been helpful in further specifying these dimensions into institutional design features, which may be relevant in explaining market performance. Institutional design features that particularly received attention include the role of the state in creating these markets, the role of trust, and markets in which one single ES is traded versus markets in which a bundle of ES is traded.

When it comes to our last research question, we did not find many articles discussing the relationship between institutional design and market performance. This small set of articles, however, contains some interesting hypotheses on the relationship between institutional design and performance, which may inform future empirical research on the relationship between the institutional design and performance of markets for watershed ecosystem services. The influence of property rights regimes has been discussed more than that of other design dimensions. Those studies inform that the clarity of related property rights can be critical to ensure the effectiveness in preservation of ecosystem services, poverty alleviation, or participation rate. The legal enforcement of the implementation may also encourage participation. Another critical design dimension discussed is the geographic market scope and scale. Suboptimal geographic scope design may lead to unequal ecosystem function distribution, and markets with too narrow trading zones may decrease market participation. In addition, too many administrative levels in the decision procedure may lead to inefficiency as well. However, there is also research informing that splitting a market in several submarkets can reduce transaction costs by controlling the number of negotiating parties, while at the same time utilizing local knowledge on cost efficiency.

Needless to say, the matrix presented in Table A3 is not exhaustive, and the direction of causation or correlation was not necessarily unidirectional. Our review pinpoints several topics that draw our further interest: (1) dynamics behind institutional design change and how the performance assessment 
could further lead to institutional change; (2) evidence of the environmental effectiveness of existing markets; and (3) efficiency of existing markets.

Author Contributions: Conceptualization, H.W., S.M. and E.v.d.K.; methodology, H.W., S.M. and E.v.d.K.; validation, H.W., S.M. and E.v.d.K.; formal analysis, H.W.; investigation, H.W.; resources, H.W., S.M. and E.v.d.K.; data curation, H.W.; writing-original draft preparation, H.W., S.M. and E.v.d.K.; writing-review and editing, H.W., S.M. and E.v.d.K.; visualization, H.W., S.M. and E.v.d.K.; supervision, S.M. and E.v.d.K.; project administration, E.v.d.K. and S.M.; funding acquisition, E.v.d.K. and S.M. All authors have read and agreed to the published version of the manuscript.

Funding: This research received no external funding.

Acknowledgments: The access to Web of Science and Open Access is guaranteed by Radboud University. The first author H.W. is supported by China Scholarship Council (CSC).

Conflicts of Interest: The authors declare no conflict of interest.

\section{Appendix A}

Table A1. Performance dimensions, indications and corresponding articles.

\begin{tabular}{|c|c|c|}
\hline Dimensions & Indications & Articles \\
\hline $\begin{array}{l}\text { Preservation of } \\
\text { ecosystem services }\end{array}$ & Such as effects on water quality or water quantity & {$[25,29,39,43,45,52,64,65,78,80,82-109]$} \\
\hline Distributional impacts & $\begin{array}{l}\text { Effects on local household livelihood, such as monetary } \\
\text { income, health, housing or employment conditions }\end{array}$ & {$[29,36,39-42,58,65,74,78,88,89,94,97,100,104,107,109-119]$} \\
\hline Efficiency & $\begin{array}{c}\text { To be cost effective or have maximized profits or with } \\
\text { comparably higher benefits/incomes }\end{array}$ & {$[65,88,89,104,114,115,120-125]$} \\
\hline Participation & $\begin{array}{c}\text { Participation rate or participant number or } \\
\text { participation tendency }\end{array}$ & {$[52,57,67,73,82,83,101,105,110,126-137]$} \\
\hline
\end{tabular}

Table A2. Institutional design dimensions, indications and corresponding articles.

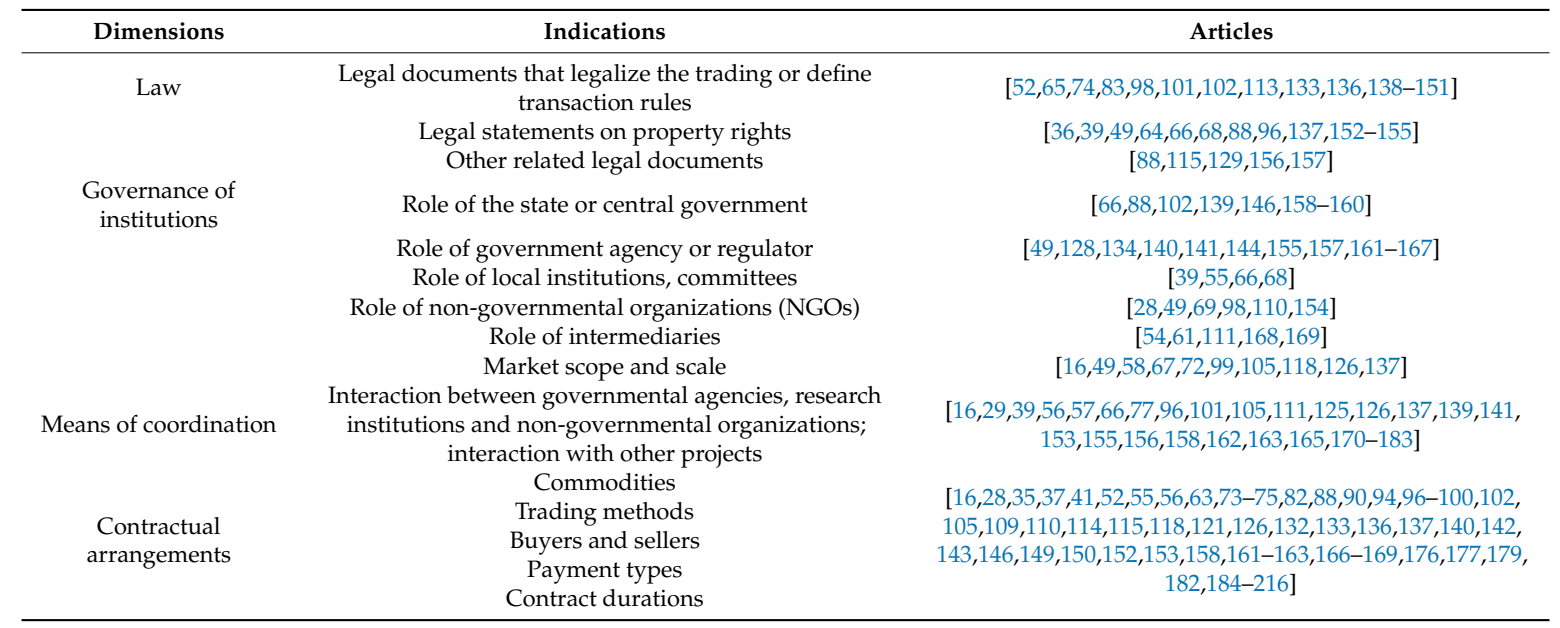

Note: Contractual arrangements were not distinguished considering most articles cover not only one indication. 
Table A3. Corresponding articles in the Relationship matrix.

\begin{tabular}{|c|c|c|c|c|c|}
\hline Dimensions & Market Types & Law & Governance & $\begin{array}{c}\text { Means of } \\
\text { Coordination }\end{array}$ & $\begin{array}{c}\text { Contractual } \\
\text { Arrangements }\end{array}$ \\
\hline \multirow{2}{*}{$\begin{array}{c}\text { Preservation of } \\
\text { ecosystem services }\end{array}$} & PES/PWS & [65] & [16] & & {$[16,166,192]$} \\
\hline & Water quality trading & [64] & [102] & & {$[64]$} \\
\hline Distributional impacts & PES/PWS & {$[36,68,113]$} & {$[68,170]$} & & {$[107,192]$} \\
\hline \multicolumn{6}{|l|}{ Efficiency } \\
\hline $\begin{array}{c}\text { Participation } \\
\text { rate/participant number }\end{array}$ & PES/PWS & {$[52,129]$} & & & {$[73,132,133]$} \\
\hline \multirow[t]{2}{*}{$\begin{array}{c}\text { General claims } \\
\text { (efficient/successful/ } \\
\text { effective/sustainable/ } \\
\text { mature/best) }\end{array}$} & $\begin{array}{c}\text { PES/PWS } \\
\text { Mitigation Banking }\end{array}$ & $\begin{array}{c}{[49,66,98,153]} \\
{[144]}\end{array}$ & $\begin{array}{c}{[39,49,66,72,153,154,167,171]} \\
{[163]}\end{array}$ & [134] & {$[55,75,167]$} \\
\hline & General & [85] & [85] & {$[105,163,181]$} & \\
\hline
\end{tabular}

\section{References}

1. Postel, S.L.; Thompson, B.H. Watershed protection: Capturing the benefits of nature's water supply services. Nat. Resour. Forum 2005, 29, 98-108. [CrossRef]

2. MEA. Ecosystems and Human Well-Being; Millennium Ecosystem Assessment: Washington, DC, USA, 2005; ISBN 1-59726-040-1.

3. Costanza, R.; de Groot, R.; Braat, L.; Kubiszewski, I.; Fioramonti, L.; Sutton, P.; Farber, S.; Grasso, M. Twenty years of ecosystem services: How far have we come and how far do we still need to go? Ecosyst. Serv. 2017, 28, 1-16. [CrossRef]

4. Gómez-Baggethun, E.; de Groot, R.; Lomas, P.L.; Montes, C. The history of ecosystem services in economic theory and practice: From early notions to markets and payment schemes. Ecol. Econ. 2010, 69, 1209-1218. [CrossRef]

5. Doyle, M.W.; Yates, A.J. Stream ecosystem service markets under no-net-loss regulation. Ecol. Econ. 2010, 69, 820-827. [CrossRef]

6. EEA (European Environment Agency). The Common International Classification of Ecosystem Services (CICES) V5.1 Spreadsheet. Available online: https://cices.eu/resources/ (accessed on 4 August 2020).

7. Haines-Young, R.; Potschin, M. Common International Classification of Ecosystem Services (CICES) V5.1 and Guidance on the Application of the Revised Structure. Available online: https://cices.eu/resources/ (accessed on 4 August 2020).

8. Katila, M.; Puustjärvi, E. Markets for forest environmental services: Reality and potential. Unasylva 2004, 55, 53-58.

9. Kolinjivadi, V.K.; Adamowski, J.; Kosoy, N. Recasting payments for ecosystem services (PES) in water resource management: A novel institutional approach. Ecosyst. Serv. 2014, 10, 144-154. [CrossRef]

10. Muradian, R.; Arsel, M.; Pellegrini, L.; Adaman, F.; Aguilar, B.; Agarwal, B.; Corbera, E.; De Blas, D.E.; Leroy, P.; May, P.; et al. Payments for ecosystem services and the fatal attraction of win-win solutions. Conserv. Lett. 2013, 6, 274-279. [CrossRef]

11. Sullivan, S. Banking nature? The spectacular financialisation of environmental. Antipode 2013, 45, $197-217$. [CrossRef]

12. Sullivan, S. On 'Natural Capital', 'Fairy Tales' and Ideology. Dev. Chang. 2017, 48, 397-423. [CrossRef]

13. Coase, R.H. The Problem of Social Cost; Palgrave Macmillan: London, UK, 1960.

14. Lai, L.W.C.; Hung, C.W.Y. The inner logic of the Coase Theorem and a Coasian planning research agenda. Environ. Plan. B Plan. Des. 2008, 35, 207-226. [CrossRef]

15. Engel, S.; Pagiola, S.; Wunder, S. Designing payments for environmental services in theory and practice: An overview of the issues. Ecol. Econ. 2008, 5, 663-674. [CrossRef]

16. Brouwer, R.; Tesfaye, A.; Pauw, P. Meta-analysis of institutional-economic factors explaining the environmental performance of payments for watershed services. Environ. Conserv. 2011, 38, 380-392. [CrossRef]

17. Wunder, S.; Engel, S.; Pagiola, S. Taking stock: A comparative analysis of payments for environmental services programs in developed and developing countries. Ecol. Econ. 2008, 65, 834-852. [CrossRef]

18. Wunder, S. Payments for Environmental Services: Some Nuts and Bolts. CIFOR Occasional Paper No.42; Center for International Forestry Research: Bogor, Indonesia, 2005; pp. 16-20. ISBN 0854-9818. 
19. Shilling, J.D.; Osha, J. Paying for Environmental Stewardship; WWF Macroeconomics for Sustainable Development Program Office: Washington, DC, USA, 2003.

20. Gough, D.; Oliver, S.; Thomas, J. Introducing systematic reviews. In An Introduction to Systematic Reviews; SAGE Publications Ltd: London, UK, 2012; pp. 1-16.

21. Adhikari, K.; Hartemink, A.E. Linking soils to ecosystem services-A global review. Geoderma 2016, 262, 101-111. [CrossRef]

22. Van den Belt, M.; Stevens, S.M. Transformative agenda, or lost in the translation? A review of top-cited articles in the first four years of Ecosystem Services. Ecosyst. Serv. 2016, 22, 60-72. [CrossRef]

23. Gasparatos, A.; Stromberg, P.; Takeuchi, K. Biofuels, ecosystem services and human wellbeing: Putting biofuels in the ecosystem services narrative. Agric. Ecosyst. Environ. 2011, 142, 111-128. [CrossRef]

24. Moher, D.; Liberati, A.; Tetzlaff, J.; Altman, D.G.; Grp, P. Preferred reporting items for systematic reviews and meta-analyses: The PRISMA statement (Reprinted from Annals of Internal Medicine). Phys. Ther. 2009, 89, 873-880. [CrossRef]

25. Guswa, A.J.; Brauman, K.A.; Brown, C.; Hamel, P.; Keeler, B.L.; Sayre, S.S. Ecosystem services: Challenges and opportunities for hydrologic modeling to support decision making. Water Resour. Res. 2014, 50, 4535-4544. [CrossRef]

26. United Nations Statistics Division UNSD-Methodology. Available online: https://unstats.un.org/unsd/ methodology/m49/ (accessed on 13 August 2017).

27. Ojea, E.; Martin-ortega, J.; Chiabai, A. Defining and classifying ecosystem services for economic valuation: The case of forest water services. Environ. Sci. Policy 2012, 19-20, 1-15. [CrossRef]

28. Bennett, D.E.; Gosnell, H.; Lurie, S.; Duncan, S. Utility engagement with payments for watershed services in the United States. Ecosyst. Serv. 2014, 8, 56-64. [CrossRef]

29. Chen, C.; König, H.J.; Matzdorf, B.; Zhen, L. The institutional challenges of payment for ecosystem service program in China: A review of the effectiveness and implementation of sloping land conversion program. Sustainability 2015, 7, 5564-5591. [CrossRef]

30. Daily, G.C. Introduction:What are Ecosystem Services? In Nature's Services: Societal Dependence On Natural Ecosystems; Gretchen, C.D., Ed.; Island Press: Washington, DC, USA, 1997; pp. 1-10. ISBN 1597267759.

31. Costanza, R.; d'Arge, R.; de Groot, R.; Farber, S.; Grasso, M.; Hannon, B.; Limburg, K.; Naeem, S.; O’Neill, R.V.; Paruelo, J.; et al. The value of the world s ecosystem services and natural capital. Nature 1997, 87, 253-260. [CrossRef]

32. De Groot, R.S.; Wilson, M.A.; Boumans, R.M.J. A typology for the classification, description, and valuation of ecosystem functions, goods and services. Ecol. Econ. 2002, 41, 393-408. [CrossRef]

33. Boyd, J.; Banzhaf, S. What are ecosystem services? The need for standardized environmental accounting units: Ecological Economics of Coastal Disasters-Coastal Disasters Special Section. Ecol. Econ. 2006, 63, 616-626. [CrossRef]

34. TEEB. Mainstreaming the Economics of Nature; UNEP: Nairobi, Kenya, 2010; ISBN 9783981341034.

35. Deal, R.L.; Cochran, B.; LaRocco, G. Bundling of ecosystem services to increase forestland value and enhance sustainable forest management. For. Policy Econ. 2012, 17, 69-76. [CrossRef]

36. Landell-mills, N.; Porras, I.T. Silver Bullet or Fools' Gold? A Global Review of Markets for Forest Environmental Services and Their Impact on the Poor; Instruments for Sustainable Private Sector Forestry Series; International Institute for Environment and Development: London, UK, 2002.

37. Jack, B.K.; Kousky, C.; Sims, K.R.E. Designing payments for ecosystem services: Lessons from previous experience with incentive-based mechanisms. Proc. Natl. Acad. Sci. USA 2008, 105, 9465-9470. [CrossRef]

38. Huber-Stearns, H.R.; Goldstein, J.H.; Cheng, A.S.; Toombs, T.P. Institutional analysis of payments for watershed services in the western United States. Ecosyst. Serv. 2015, 16, 83-93. [CrossRef]

39. Bullock, J.M.; Aronson, J.; Newton, A.C.; Pywell, R.F.; Rey-Benayas, J.M. Restoration of ecosystem services and biodiversity: Conflicts and opportunities. Trends Ecol. Evol. 2011, 26, 541-549. [CrossRef]

40. Asbjornsen, H.; Mayer, A.S.; Jones, K.W.; Selfa, T.; Saenz, L.; Kolka, R.K.; Halvorsen, K.E. Assessing impacts of payments for watershed services on sustainability in coupled human and natural systems. Bioscience 2015, 65, 579-591. [CrossRef]

41. Pham, T.; Campbell, B.M.; Garnett, S. Lessons for pro-poor payments for environmental services: An analysis of projects in Vietnam. Asia Pac. J. Public Adm. 2009, 31, 117-133. 
42. Grieg-Gran, M.; Porras, I.; Wunder, S. How can market mechanisms for forest environmental services help the poor? Preliminary lessons from Latin America. World Dev. 2005, 33, 1511-1527. [CrossRef]

43. He, T.; Lu, Y.; Cui, Y.; Luo, Y.; Wang, M.; Meng, W.; Zhang, K.; Zhao, F. Detecting gradual and abrupt changes in water quality time series in response to regional payment programs for watershed services in an agricultural area. J. Hydrol. 2015, 525, 457-471. [CrossRef]

44. Nordblom, T.L.; Reeson, A.F.; Finlayson, J.D.; Hume, I.H.; Whitten, S.M.; Kelly, J.A. Price discovery and distribution of water rights linking upstream tree plantations to downstream water markets: Experimental results. Water Policy 2011, 13, 810-827. [CrossRef]

45. Quintero, M.; Wunder, S.; Estrada, R.D. For services rendered? Modeling hydrology and livelihoods in Andean payments for environmental services schemes. For. Ecol. Manag. 2009, 258, 1871-1880. [CrossRef]

46. Kahil, M.T.; Dinar, A.; Albiac, J. Modeling water scarcity and droughts for policy adaptation to climate change in arid and semiarid regions. J. Hydrol. 2015, 522, 95-109. [CrossRef]

47. Bremer, L.L.; Farley, K.A.; Lopez-Carr, D. What factors influence participation in payment for ecosystem services programs? An evaluation of Ecuador's SocioPáramo program. Land Use Policy 2014, 36, 122-133. [CrossRef]

48. Greiber, T. Payments for Ecosystem Services. Legal and Institutional Frameworks; IUCN: Gland, Switzerland, 2009; ISBN 9782831711768.

49. Swallow, B.M.; Leimona, B.; Yatich, T.; Velarde, S.J. The conditions for functional mechanisms of compensation and reward for environmental services. Ecol. Soc. 2010, 15, 6. [CrossRef]

50. Balana, B.B.; Catacutan, D.; Mäkelä, M. Assessing the willingness to pay for reliable domestic water supply via catchment management: Results from a contingent valuation survey in Nairobi City, Kenya. J. Environ. Plan. Manag. 2013, 56, 1511-1531. [CrossRef]

51. Tripp, J.T.B.; Dudek, D.J. Institutional guidelines for designing successful transferable rights programs. Yale J. Regul. 1989, 6, 369.

52. McElwee, P.; Nghiem, T.; Le, H.; Vu, H.; Tran, N. Payments for environmental services and contested neoliberalisation in developing countries: A case study from Vietnam. J. Rural Stud. 2014, 36, 423-440. [CrossRef]

53. Silva, R.A.; Lapola, D.M.; Patricio, G.B.; Teixeira, M.C.; Pinho, P.; Priess, J.A. Operationalizing payments for ecosystem services in Brazil's sugarcane belt: How do stakeholder opinions match with successful cases in Latin America? Ecosyst. Serv. 2016, 22, 128-138. [CrossRef]

54. Mariola, M.J. Farmers, trust, and the market solution to water pollution: The role of social embeddedness in water quality trading. J. Rural Stud. 2012, 28, 577-589. [CrossRef]

55. Young, C.E.F.; de Bakker, L.B. Payments for ecosystem services from watershed protection: A methodological assessment of the Oasis Project in Brazil. Nat. Conserv. 2014, 12, 71-78. [CrossRef]

56. Bohlen, P.J.; Lynch, S.; Shabman, L.; Clark, M.; Shukla, S.; Swain, H. Paying for environmental services from agricultural lands: An example from the northern Everglades. Front. Ecol. Environ. 2009, 7, 46-55. [CrossRef]

57. Neitzel, K.C.; Caro-Borrero, A.P.; Revollo-Fernandez, D.; Aguilar-Ibarra, A.; Ramos, A.; Almeida-Leñero, L. Paying for environmental services: Determining recognized participation under common property in a peri-urban context. For. Policy Econ. 2014, 38, 46-55. [CrossRef]

58. Branca, G.; Lipper, L.; Neves, B.; Lopa, D.; Mwanyoka, I. Payments for watershed services supporting sustainable agricultural development in Tanzania. J. Environ. Dev. 2011, 20, 278-302. [CrossRef]

59. Lapeyre, R.; Pirard, R.; Leimona, B. Payments for environmental services in Indonesia: What if economic signals were lost in translation? Land Use Policy 2015, 46, 283-291. [CrossRef]

60. Pham, T.T.; Loft, L.; Bennett, K.; Phuong, V.T.; Dung, L.N.; Brunner, J. Monitoring and evaluation of Payment for Forest Environmental Services in Vietnam: From myth to reality. Ecosyst. Serv. 2015, 16, 220-229. [CrossRef]

61. Leimona, B.; Lusiana, B.; van Noordwijk, M.; Mulyoutami, E.; Ekadinata, A.; Amaruzaman, S. Boundary work: Knowledge co-production for negotiating payment for watershed services in Indonesia. Ecosyst. Serv. 2015, 15, 45-62. [CrossRef]

62. Van de Sand, I.; Mwangi, J.K.; Namirembe, S. Can payments for ecosystem services contribute to adaptation to climate change? Insights from a watershed in Kenya. Ecol. Soc. 2014, 19, 47. [CrossRef] 
63. Goldman-Benner, R.L.; Benitez, S.; Boucher, T.; Calvache, A.; Daily, G.; Kareiva, P.; Kroeger, T.; Ramos, A. Water funds and payments for ecosystem services: Practice learns from theory and theory can learn from practice. Oryx 2012, 46, 55-63. [CrossRef]

64. Baird, J.; Belcher, K.W.; Quinn, M. Context and capacity: The potential for performance-based agricultural water quality policy. Can. Water Resour. J. 2014, 39, 421-436. [CrossRef]

65. Qu, F.; Kuyvenhoven, A.; Shi, X.; Heerink, N. Sustainable natural resource use in rural China: Recent trends and policies. China Econ. Rev. 2011, 22, 444-460. [CrossRef]

66. Daly-Hassen, H.; Pettenella, D.; Ahmed, T. Economic instruments for the sustainable management of Mediterranean watersheds. For. Syst. 2010, 19, 141-155. [CrossRef]

67. Womble, P.; Doyle, M. The geography of trading ecosystem services: A case study of wetland and stream compensatory mitigation markets. Harvard Environ. Law Rev. 2012, 36, 229-296.

68. Milder, J.C.; Scherr, S.J.; Bracer, C. Trends and future potential of payment for ecosystem services to alleviate rural poverty in developing countries. Ecol. Soc. 2010, 15, 6. [CrossRef]

69. Corbera, E.; Kosoy, N.; Martínez Tuna, M. Equity implications of marketing ecosystem services in protected areas and rural communities: Case studies from Meso-America. Glob. Environ. Chang. 2007, 17, 365-380. [CrossRef]

70. Tschakert, P. Environmental services and poverty reduction: Options for smallholders in the Sahel. Agric. Syst. 2007, 94, 75-86. [CrossRef]

71. Landell-Mills, N. Developing markets for forest environmental services: An opportunity for promoting equity while securing efficiency? In Philosophical Transactions of The Royal Society A Mathematical Physical and Engineering Sciences; Royal Society: London, UK, 2002; Volume 360, pp. 1817-1825.

72. Rolfe, J.; Greiner, R.; Windle, J.; Hailu, A. Testing for allocation efficiencies in water quality tenders across catchments, industries and pollutants: A north Queensland case study. Aust. J. Agric. Resour. Econ. 2011, 55, 518-536. [CrossRef]

73. Knoot, T.G.; Rickenbach, M.; Silbernagel, K. Payments for ecosystem services: Will a new hook net more active family forest owners? J. For. 2014, 113, 210-218. [CrossRef]

74. Kolinjivadi, V.K.; Sunderland, T. A review of two payment schemes for watershed services from China and Vietnam: The interface of government control and PES theory. Ecol. Soc. 2012, 17, 10. [CrossRef]

75. Lan, L.N.; Wichelns, D.; Milan, F.; Hoanh, C.T.; Phuong, N.D. Household opportunity costs of protecting and developing forest lands in Son La and Hoa Binh provinces, Vietnam. Int. J. Commons 2016, 10, 902-928. [CrossRef]

76. Klijn, E.H.; Koppenjan, J.F.M. Complexity in governance network theory. Complex. Gov. Netw. 2014, 1, 61-70.

77. Alston, L.J.; Andersson, K.; Smith, S.M. Payment for Environmental Services: Hypotheses and evidence. Annu. Rev. Resour. Econ. 2013, 5, 139-159. [CrossRef]

78. Wertz-Kanounnikoff, S.; Locatelli, B.; Wunder, S.; Brockhaus, M. Ecosystem-based adaptation to climate change: What scope for payments for environmental services? Clim. Dev. 2011, 3, 143-158. [CrossRef]

79. Le Tellier, V.; Carrasco, A.; Asquith, N. Attempts to determine the effects of forest cover on stream flow by direct hydrological measurements in Los Negros, Bolivia. For. Ecol. Manag. 2009, 258, 1881-1888. [CrossRef]

80. Jack, B.K. Upstream-downstream transactions and watershed externalities: Experimental evidence from Kenya. Ecol. Econ. 2009, 68, 1813-1824. [CrossRef]

81. Ioris, A.A.R. The political nexus between water and economics in Brazil: A critique of recent policy reforms. Rev. Radic. Polit. Econ. 2010, 42, 231-250. [CrossRef]

82. Maille, P.; Collins, A.R. An index approach to performance-based payments for water quality. J. Environ. Manag. 2012, 99, 27-35. [CrossRef]

83. Lovell, S.; Millock, K.; Sunding, D.L. Using water markets to improve environmental quality: Two innovative programs in Nevada. J. Soil Water Conserv. 2000, 55, 19-26.

84. Saleh, A.; Gallego, O.; Osei, E.; Lal, H.; Gross, C.; McKinney, S.; Cover, H. Nutrient Tracking Tool-a user-friendly tool for calculating nutrient reductions for water quality trading. J. Soil Water Conserv. 2011, 66, 400-410. [CrossRef]

85. Tallis, H.; Goldman, R.; Uhl, M.; Brosi, B. Integrating conservation and development in the field: Implementing ecosystem service projects. Front. Ecol. Environ. 2009, 7, 12-20. [CrossRef]

86. Palmer, M.A.; Filoso, S. Restoration of ecosystem services for environmental markets. Science 2009, 325, 575-576. [CrossRef] [PubMed] 
87. Pattanayak, S.K.; Wunder, S.; Ferraro, P.J. Show me the money: Do payments supply environmental services in developing countries? Rev. Environ. Econ. Policy 2010, 4, 254-274. [CrossRef]

88. Pettenella, D.; Vidale, E.; Gatto, P.; Secco, L. Paying for water-related forest services: A survey on Italian payment mechanisms. IForest 2012, 5, 210-215. [CrossRef]

89. Parson, E.A.; Kravitz, E.L. Market instruments for the sustainability transition. Annu. Rev. Environ. Resour. 2013, 38, 415-440. [CrossRef]

90. Bellver-Domingo, A.; Hernández-Sancho, F.; Molinos-Senante, M. A review of Payment for Ecosystem Services for the economic internalization of environmental externalities: A water perspective. Geoforum 2016, 70, 115-118. [CrossRef]

91. De Melo, N.A.; Delevati, D.M.; Putzke, J.; Lobo, E.A. Phytosociological survey in water preservation areas, Southern, Brazil. Bot. Rev. 2016, 82, 359-370. [CrossRef]

92. Ruiz-Jiménez, M.; Valtierra-Pacheco, E. Impact of Payment for Hydrological Environmental Services in forests from three ejidos in Texcoco, México. Agric. Soc. Desarro 2017, 14, 511-531.

93. Immerzeel, W.; Stoorvogel, J.; Antle, J. Can payments for ecosystem services secure the water tower of Tibet? Agric. Syst. 2008, 96, 52-63. [CrossRef]

94. Robertson, M.; Hayden, N. Evaluation of a market in wetland credits: Entrepreneurial wetland banking in Chicago. Conserv. Biol. 2008, 22, 636-646. [CrossRef] [PubMed]

95. Lu, Y.; He, T. Assessing the effects of regional payment for watershed services program on water quality using an intervention analysis model. Sci. Total Environ. 2014, 493, 1056-1064. [CrossRef] [PubMed]

96. Sovacool, B.K. Using ecosystem valuation to protect the Atlantic Rainforest: The case of the oasis project. Soc. Nat. Resour. 2011, 24, 1096-1104. [CrossRef]

97. Turpie, J.K.; Marais, C.; Blignaut, J.N. The working for water programme: Evolution of a payments for ecosystem services mechanism that addresses both poverty and ecosystem service delivery in South Africa. Ecol. Econ. 2008, 65, 788-798. [CrossRef]

98. Fauzi, A.; Anna, Z. The complexity of the institution of payment for environmental services: A case study of two Indonesian PES schemes. Ecosyst. Serv. 2013, 6, 54-63. [CrossRef]

99. Martin-Ortega, J.; Ojea, E.; Roux, C. Payments for water ecosystem services in Latin America: A literature review and conceptual model. Ecosyst. Serv. 2013, 6, 122-132. [CrossRef]

100. Mauerhofer, V.; Hubacek, K.; Coleby, A. From polluter pays to provider gets: Distribution of rights and costs under payments for ecosystem services. Ecol. Soc. 2013, 18, 41. [CrossRef]

101. Grolleau, G.; McCann, L.M.J. Designing watershed programs to pay farmers for water quality services: Case studies of Munich and New York City. Ecol. Econ. 2012, 76, 87-94. [CrossRef]

102. Mariola, M.J. The commodification of pollution and a preemptive double movement in environmental governance: The case of water quality trading. Organ. Environ. 2011, 24, 231-248. [CrossRef]

103. Castro, A.J.; Martín-López, B.; López, E.; Plieninger, T.; Alcaraz-Segura, D.; Vaughn, C.C.; Cabello, J. Do protected areas networks ensure the supply of ecosystem services? Spatial patterns of two nature reserve systems in semi-arid Spain. Appl. Geogr. 2015, 60, 1-9. [CrossRef]

104. Zheng, H.; Robinson, B.E.; Liang, Y.-C.; Polasky, S.; Ma, D.-C.; Wang, F.-C.; Ruckelshaus, M.; Ouyang, Z.-Y.; Daily, G.C. Benefits, costs, and livelihood implications of a regional payment for ecosystem service program. Proc. Natl. Acad. Sci. USA 2013, 110, 16681-16686. [CrossRef] [PubMed]

105. Asbjornsen, H.; Manson, R.H.; Scullion, J.J.; Holwerda, F.; Muñoz-Villers, L.E.; Alvarado-Barrientos, M.S.; Geissert, D.; Dawson, T.E.; McDonnell, J.J.; Adrian Bruijnzeel, L. Interactions between payments for hydrologic services, landowner decisions, and ecohydrological consequences: Synergies and disconnection in the cloud forest zone of central Veracruz, Mexico. Ecol. Soc. 2017, 22. [CrossRef]

106. Muenich, R.L.; Kalcic, M.M.; Winsten, J.; Fisher, K.; Day, M.; O’Neil, G.; Scavia, D.; Wang, Y.-C. Pay-for-performance conservation using SWAT highlights need for field-level agricultural conservation. Trans. ASABE 2017, 60, 1925-1937. [CrossRef]

107. Lewison, R.L.; An, L.; Chen, X. Reframing the payments for ecosystem services framework in a coupled human and natural systems context strengthening the integration between ecological and human dimensions. Ecosyst. Health Sustain. 2017, 3, 1335931. [CrossRef]

108. Rodríguez de Francisco, J.C.; Budds, J. Payments for environmental services and control over conservation of natural resources: The role of public and private sectors in the conservation of the Nima watershed, Colombia. Ecol. Econ. J. 2015, 117, 295-302. [CrossRef] 
109. Tang, Z.; Shi, Y.; Nan, Z.; Xu, Z. The economic potential of payments for ecosystem services in water conservation: A case study in the upper reaches of Shiyang River basin, northwest China. Environ. Dev. Econ. 2012, 17, 445-460. [CrossRef]

110. Rodríguez de Francisco, J.C.; Budds, J.; Boelens, R. Payment for environmental services and unequal resource control in Pimampiro, Ecuador. Soc. Nat. Resour. 2013, 26, 1217-1233. [CrossRef]

111. Sraswat, C.; Kumar, P.; Kem, D.; Avtar, R.; Ramanathan, A. Payment of ecosystem service to alleviate poverty from Kyrgyz Republic in central Asia considering climate change and extreme weather condition. J. Clim. Chang. 2015, 1, 119-128. [CrossRef]

112. Nieratkaa, L.; Bray, D.; Mozumder, P. Can payments for environmental services strengthen social capital, encourage distributional equity, and reduce poverty? Conserv. Soc. 2015, 13, 345-355.

113. Suyanto, S.; Khususiyah, N.; Leimona, B. Poverty and environmental services: Case study in Way Besai Watershed, Lampung Province, Indonesia. Ecol. Soc. 2007, 12. [CrossRef]

114. Wunder, S.; Albán, M. Decentralized payments for environmental services: The cases of Pimampiro and PROFAFOR in Ecuador. Ecol. Econ. 2008, 65, 685-698. [CrossRef]

115. Pirard, R. Payments for environmental services (PES) in the public policy landscape: "Mandatory" spices in the Indonesian recipe. For. Policy Econ. 2012, 18, 23-29. [CrossRef]

116. Lopa, D.; Mwanyoka, I.; Jambiya, G.; Massoud, T.; Harrison, P.; Ellis-Jones, M.; Blomley, T.; Leimona, B.; van Noordwijk, M.; Burgess, N.D. Towards operational payments for water ecosystem services in Tanzania: A case study from the Uluguru Mountains. Oryx 2012, 46, 34-44. [CrossRef]

117. Bendor, T.K.; Riggsbee, J.A.; Doyle, M. Risk and markets for ecosystem services. Environ. Sci. Technol. 2011, 45, 10322-10330. [CrossRef] [PubMed]

118. De Koning, M.; de Beer, F. Payment for ecosystem services through renewable energy generation to promote community based natural resource management in the Blyde in South Africa. Dev. South. Afr. 2013, 30, 238-249. [CrossRef]

119. Kwayu, E.J.; Paavola, J.; Sallu, S.M. The livelihood impacts of the Equitable Payments for Watershed Services (EPWS) Program in Morogoro, Tanzania. Environ. Dev. Econ. 2017, 22, 328-349. [CrossRef]

120. Lowell, K.; Drohan, J.; Hajek, C.; Beverly, C.; Lee, M. A science-driven market-based instrument for determining the cost of environmental services: A comparison of two catchments in Australia. Ecol. Econ. 2007, 64, 61-69. [CrossRef]

121. Roumasset, J.; Wada, C.A. A dynamic approach to PES pricing and finance for interlinked ecosystem services: Watershed conservation and groundwater management. Ecol. Econ. 2013, 87, 24-33. [CrossRef]

122. Susaeta, A.; Soto, J.R.; Adams, D.C.; Allen, D.L. Economic sustainability of payments for water yield in slash pine plantations in Florida. Water 2016, 8, 382. [CrossRef]

123. Mcdonald, R.I. The effectiveness of conservation interventions to overcome the urban-Environmental paradox. Ann. N. Y. Acad. Sci. 2015, 1355, 1-14. [CrossRef]

124. Jenkins, W.A.; Murray, B.C.; Kramer, R.A.; Faulkner, S.P. Valuing ecosystem services from wetlands restoration in the Mississippi Alluvial Valley. Ecol. Econ. 2010, 69, 1051-1061. [CrossRef]

125. Talberth, J.; Selman, M.; Walker, S.; Gray, E. Pay for Performance: Optimizing public investments in agricultural best management practices in the Chesapeake Bay Watershed. Ecol. Econ. 2015, 118, $252-261$. [CrossRef]

126. Lurie, S.; Bennett, D.E.; Duncan, S.; Gosnell, H.; Hunter, M.L.; Morzillo, A.T.; Moseley, C.; Nielsen-Pincus, M.; Parker, R.; White, E.M. PES marketplace development at the local scale: The Eugene Water and Electric Board as a local watershed services marketplace driver. Ecosyst. Serv. 2013, 6, 93-103. [CrossRef]

127. Kwayu, E.J.; Sallu, S.M.; Paavola, J. Farmer participation in the equitable payments for watershed services in Morogoro, Tanzania. Ecosyst. Serv. 2014, 7, 1-9. [CrossRef]

128. Zanella, M.A.; Schleyer, C.; Speelman, S. Why do farmers join Payments for Ecosystem Services (PES) schemes? An Assessment of PES water scheme participation in Brazil. Ecol. Econ. 2014, 105, 166-176. [CrossRef]

129. Sims, K.R.E.; Alix-Garcia, J.M.; Shapiro-Garza, E.; Fine, L.R.; Radeloff, V.C.; Aronson, G.; Castillo, S.; Ramirez-Reyes, C.; Yañez-Pagans, P. Improving environmental and social targeting through adaptive management in Mexico's Payments for Hydrological Services program. Conserv. Biol. 2014, 28, 1151-1159. [CrossRef] 
130. Caro-Borrero, A.; Corbera, E.; Neitzel, K.C.; Almeida-Leñero, L. "We are the city lungs": Payments for ecosystem services in the outskirts of Mexico City. Land Use Policy 2015, 43, 138-148. [CrossRef]

131. Page, G.; Ridoutt, B.; Creeper, D.; Bellotti, B. A framework for assessing local PES proposals. Land Use Policy 2015, 43, 37-41. [CrossRef]

132. De Martino, S.; Kondylis, F.; Zwager, A. Protecting the environment for love or money? The role of motivation and incentives in shaping demand for payments for environmental services programs. Public Financ. Rev. 2017, 45, 68-96. [CrossRef]

133. Richards, R.C.; Kennedy, C.J.; Lovejoy, T.E.; Brancalion, P.H.S. Considering farmer land use decisions in efforts to 'scale up' Payments for Watershed Services. Ecosyst. Serv. 2017, 23, 238-247. [CrossRef]

134. Muñoz-Piña, C.; Guevara, A.; Torres, J.M.; Braña, J. Paying for the hydrological services of Mexico's forests: Analysis, negotiations and results. Ecol. Econ. 2008, 65, 725-736. [CrossRef]

135. Bennett, M.T. China's sloping land conversion program: Institutional innovation or business as usual? Ecol. Econ. 2008, 65, 699-711. [CrossRef]

136. Smith, L.; Inman, A.; Cherrington, R. The potential of land conservation agreements for protection of water resources. Environ. Sci. Policy 2012, 24, 92-100. [CrossRef]

137. Cochran, B.; Logue, C. A Watershed approach to improve water quality: Case study of Clean Water Services' Tualatin River program. J. Am. Water Resour. Assoc. 2011, 47, 29-38. [CrossRef]

138. Köbbing, J.F.; Beckmann, V.; Thevs, N.; Peng, H.; Zerbe, S. Investigation of a traditional reed economy (Phragmites australis) under threat: Pulp and paper market, values and Netchain at Wuliangsuhai Lake, Inner Mongolia, China. Wetl. Ecol. Manag. 2016, 24, 357-371. [CrossRef]

139. Shapiro-Garza, E. Contesting the market-based nature of Mexico's national payments for ecosystem services programs: Four sites of articulation and hybridization. Geoforum 2013, 46, 5-15. [CrossRef]

140. Suhardiman, D.; Wichelns, D.; Lestrelin, G.; Hoanh, C.T. Payments for ecosystem services in Vietnam: Market-based incentives or state control of resources? Ecosyst. Serv. 2013, 6, 64-71. [CrossRef]

141. Dai, L. Exploring China's approach to implementing 'eco-compensation' schemes: The Lake Tai watershed as case study considered through a legal lens. Water Int. 2014, 39, 755-773. [CrossRef]

142. Xiong, Y.; Wang, K. Eco-compensation effects of the wetland recovery in Dongting Lake area. J. Geogr. Sci. 2010, 20, 389-405. [CrossRef]

143. Merrett, S. The urban market for farmers' water rights. Irrig. Drain. 2003, 52, 319-326. [CrossRef]

144. BenDor, T.K.; Riggsbee, J.A. A survey of entrepreneurial risk in U.S. wetland and stream compensatory mitigation markets. Environ. Sci. Policy 2011, 14, 301-314. [CrossRef]

145. Woodward, R.T. Double-dipping in environmental markets. J. Environ. Econ. Manag. 2011, 61, $153-169$. [CrossRef]

146. Wendland, K.J.; Honzák, M.; Portela, R.; Vitale, B.; Rubinoff, S.; Randrianarisoa, J. Targeting and implementing payments for ecosystem services: Opportunities for bundling biodiversity conservation with carbon and water services in Madagascar. Ecol. Econ. 2010, 69, 2093-2107. [CrossRef]

147. Fisher, B.; Kulindwa, K.; Mwanyoka, I.; Turner, R.K.; Burgess, N.D. Common pool resource management and PES: Lessons and constraints for water PES in Tanzania. Ecol. Econ. 2010, 69, 1253-1261. [CrossRef]

148. Wang, P.; Wolf, S.A.; Lassoie, J.P.; Poe, G.L.; Morreale, S.J.; Su, X.; Dong, S. Promise and reality of market-based environmental policy in China: Empirical analyses of the ecological restoration program on the Qinghai-Tibetan Plateau. Glob. Environ. Chang. 2016, 39, 35-44. [CrossRef]

149. Richards, R.C.; Rerolle, J.; Aronson, J.; Pereira, P.H.; Gonçalves, H.; Brancalion, P.H.S. Governing a pioneer program on payment for watershed services: Stakeholder involvement, legal frameworks and early lessons from the Atlantic forest of Brazil. Ecosyst. Serv. 2015, 16, 23-32. [CrossRef]

150. Robertson, M.; BenDor, T.K.; Lave, R.; Riggsbee, A.; Ruhl, J.B.; Doyle, M. Stacking ecosystem services. Front. Ecol. Environ. 2014, 12, 186-193. [CrossRef]

151. Ioris, A.A.R. The neoliberalization of water in Lima, Peru. Polit. Geogr. 2012, 31, 266-278. [CrossRef]

152. Garnache, C.; Swinton, S.M.; Herriges, J.A.; Lupi, F.; Stevenson, R.J. Solving the phosphorus pollution puzzle: Synthesis and directions for future research. Am. J. Agric. Econ. 2016, 98, 1334-1359. [CrossRef]

153. Miller, R.; Nielsen, E.; Huang, C.H. Ecosystem service valuation through wildfire risk mitigation: Design, governance, and outcomes of the Flagstaff Watershed Protection Project (FWPP). Forests 2017, 8, 142. [CrossRef] 
154. Salzman, J. The promise and perils of payments for ecosystem services. Int. J. Innov. Sustain. Dev. 2005, 1, 5-20. [CrossRef]

155. Liu, G.; Zhang, H.; Wan, J. Chinese policies and practices regarding payments for ecological services in watersheds. Chin. J. Popul. Environ. 2008, 6, 36-43.

156. Garrick, D.; Siebentritt, M.A.; Aylward, B.; Bauer, C.J.; Purkey, A. Water markets and freshwater ecosystem services: Policy reform and implementation in the Columbia and Murray-Darling Basins. Ecol. Econ. 2009, 69, 366-379. [CrossRef]

157. Svendsen, M.; Rosegrant, M.W. Irrigation development in Southeast Asia beyond 2000: Will the future be like the past? Water Int. 1994, 19, 25-35. [CrossRef]

158. Muñoz Escobar, M.; Hollaender, R.; Pineda Weffer, C. Institutional durability of payments for watershed ecosystem services: Lessons from two case studies from Colombia and Germany. Ecosyst. Serv. 2013, 6, 46-53. [CrossRef]

159. Libanio, P.A.C. Pollution of inland waters in Brazil: The case for goal-oriented initiatives. Water Int. 2015, 40, 513-533. [CrossRef]

160. Jourdain, D.; Boere, E.; van den Berg, M.; Dang, Q.D.; Cu, T.P.; Affholder, F.; Pandey, S. Water for forests to restore environmental services and alleviate poverty in Vietnam: A farm modeling approach to analyze alternative PES programs. Land Use Policy 2014, 41, 423-437. [CrossRef]

161. Raffensperger, J.F.; Prabodanie, R.A.R.; Kostel, J.A. A smart market for nutrient credit trading to incentivize wetland construction. J. Hydrol. 2017, 546, 248-261. [CrossRef]

162. Suich, H.; Lugina, M.; Muttaqin, M.Z.; Alviya, I.; Sari, G.K. Payments for ecosystem services in Indonesia. Oryx 2017, 51, 489-497. [CrossRef]

163. Ribaudo, M.; Greene, C.; Hansen, L.; Hellerstein, D. Ecosystem services from agriculture: Steps for expanding markets. Ecol. Econ. 2010, 69, 2085-2092. [CrossRef]

164. McNEELY, J.A. Using economic instruments to overcome obstacles to in situ conservation of biodiversity. Integr. Zool. 2006, 1, 25-31. [CrossRef] [PubMed]

165. Toderi, M.; Francioni, M.; Seddaiu, G.; Roggero, P.P.; Trozzo, L.; D’Ottavio, P. Bottom-up design process of agri-environmental measures at a landscape scale: Evidence from case studies on biodiversity conservation and water protection. Land Use Policy 2017, 68, 295-305. [CrossRef]

166. Webb, A.A.; Martin, P.V. Potential of a payments for ecosystem services scheme to improve the quality of water entering the Sydney catchments. Water Policy 2016, 18, 91-110. [CrossRef]

167. Sattler, C.; Trampnau, S.; Schomers, S.; Meyer, C.; Matzdorf, B. Multi-classification of payments for ecosystem services: How do classification characteristics relate to overall PES success? Ecosyst. Serv. 2013, 6, 31-45. [CrossRef]

168. Raes, L.; Loft, L.; le Coq, J.F.; van Huylenbroeck, G.; van Damme, P. Towards market- or command-based governance? The evolution of payments for environmental service schemes in Andean and Mesoamerican countries. Ecosyst. Serv. J. 2016, 18, 20-32. [CrossRef]

169. Jaung, W.; Putzel, L.; Bull, G.Q.; Kozak, R. Markum Certification of forest watershed services: A Q methodology analysis of opportunities and challenges in Lombok, Indonesia. Ecosyst. Serv. 2016, 22, 51-59. [CrossRef]

170. McAfee, K.; Shapiro, E.N. Payments for ecosystem services in Mexico: Nature, neoliberalism, social movements, and the state. Ann. Assoc. Am. Geogr. 2010, 100, 579-599. [CrossRef]

171. Blignaut, J.; Mander, M.; Schulze, R.; Horan, M.; Dickens, C.; Pringle, C.; Mavundla, K.; Mahlangu, I.; Wilson, A.; McKenzie, M.; et al. Restoring and managing natural capital towards fostering economic development: Evidence from the Drakensberg, South Africa. Ecol. Econ. 2010, 69, 1313-1323. [CrossRef]

172. Heberling, M.T.; García, J.H.; Thurston, H.W. Does encouraging the use of wetlands in water quality trading programs make economic sense? Ecol. Econ. 2010, 69, 1988-1994. [CrossRef]

173. Zhu, X.; Li, D.; Rodriguez, L.F. An agent-based simulation model of a nutrient trading market for natural resources management. Math. Comput. Model. 2011, 54, 987-994. [CrossRef]

174. Abildtrup, J.; Jensen, F.; Dubgaard, A. Does the Coase theorem hold in real markets? An application to the negotiations between waterworks and farmers in Denmark. J. Environ. Manag. 2012, 93, 169-176. [CrossRef] [PubMed]

175. Rodríguez de Francisco, J.C.; Boelens, R. Payment for environmental services and power in the Chamachán Watershed, Ecuador. Hum. Organ. 2014, 73, 351-362. [CrossRef] 
176. Wang, H.; Dong, Z.; Xu, Y.; Ge, C. Eco-compensation for watershed services in China. Water Int. 2016, 41, 271-289. [CrossRef]

177. Del Corso, J.P.; Nguyen, T.D.P.G.; Kephaliacos, C. Acceptance of a payment for ecosystem services scheme: The decisive influence of collective action. Environ. Values 2017, 26, 177-202. [CrossRef]

178. Grima, N.; Singh, S.J.; Smetschka, B. Decision making in a complex world: Using OPTamos in a multi-criteria process for land management in the Cuitzmala watershed in Mexico. Land Use Policy 2017, 67, 73-85. [CrossRef]

179. Weyerhaeuser, H.; Wilkes, A.; Kahrl, F. Local impacts and responses to regional forest conservation and rehabilitation programs in China's northwest Yunnan province. Agric. Syst. 2005, 85, 234-253. [CrossRef]

180. Zhong, L.J.; Mol, A.P.J. Participatory environmental governance in China: Public hearings on urban water tariff setting. J. Environ. Manag. 2008, 88, 899-913. [CrossRef]

181. Bendor, T.K.; Doyle, M.W. Planning for ecosystem service markets. J. Am. Plan. Assoc. 2010, 76, 59-72. [CrossRef]

182. Huang, C.C.; Tsai, M.H.; Lin, W.T.; Ho, Y.F.; Tan, C.H.; Sung, Y.L. Experiences of water transfer from the agricultural to the non-agricultural sector in Taiwan. Paddy Water Environ. 2007, 5, 271-277. [CrossRef]

183. Balvanera, P.; Uriarte, M.; Almeida-Leñero, L.; Altesor, A.; DeClerck, F.; Gardner, T.; Hall, J.; Lara, A.; Laterra, P.; Peña-Claros, M.; et al. Ecosystem services research in Latin America: The state of the art. Ecosyst. Serv. 2012, 2, 56-70. [CrossRef]

184. Olmstead, S.M. The economics of managing scarce water resources. Rev. Environ. Econ. Policy 2010, 4, 179-198. [CrossRef]

185. Dong, Z.; Yan, Y.; Duan, J.; Zhou, Q.; Huang, X.; Zhu, X.; Zhao, J. Computing payment for ecosystem services in watersheds: An analysis of the Middle Route Project of South-to-North Water Diversion in China. J. Environ. Sci. 2011, 23, 2005-2012. [CrossRef]

186. Bai, Y.; Wang, R.; Jin, J. Water eco-service assessment and compensation in a coal mining region-A case study in the Mentougou District in Beijing. Ecol. Complex. 2011, 8, 144-152. [CrossRef]

187. Arias, M.E.; Cochrane, T.; Killeen, T.J.; Farrell, T. Paying the forest for electricity: A modelling framework to market forest conservation as payment for ecosystem services benefiting hydropower generation. Environ. Conserv. 2011, 38, 473-484. [CrossRef]

188. Gallego-Ayala, J.; Gomez-Limon, J.A.; Arriaza, M. Irrigation water pricing instruments: A sustainability assessment. Span. J. Agric. Res. 2011, 9, 981. [CrossRef]

189. Han, M.; Cui, J.; Hao, Z.; Wang, Y.; Wang, R. Eco-compensation of wetlands in Yellow River Delta of Shandong Province, China. Chin. Geogr. Sci. 2012, 22, 119-126. [CrossRef]

190. Townsend, P.V.; Harper, R.J.; Brennan, P.D.; Dean, C.; Wu, S.; Smettem, K.R.J.; Cook, S.E. Multiple environmental services as an opportunity for watershed restoration. For. Policy Econ. 2012, 17, 45-58. [CrossRef]

191. Caplan, A.J. Water quality trading in the presence of abatement-cost sharing. Contemp. Econ. Policy 2013, 31, 279-290. [CrossRef]

192. Hendrayanto, H.; Sudomo, S. Hydrological services of forests and their compensation initiatives. J. Manaj. Hutan Trop. J. Trop. For. Manag. 2013, 19, 79-84. [CrossRef]

193. Meijaard, E.; Wunder, S.; Guariguata, M.R.; Sheil, D. What scope for certifying forest ecosystem services? Ecosyst. Serv. 2014, 7, 160-166. [CrossRef]

194. Campbell, E.T.; Tilley, D.R. The eco-price: How environmental emergy equates to currency. Ecosyst. Serv. 2014, 7, 128-140. [CrossRef]

195. BenDor, T.K.; Guo, T.; Yates, A.J. Optimal advanced credit releases in ecosystem service markets. Environ. Manag. 2014, 53, 496-509. [CrossRef] [PubMed]

196. Ribaudo, M.; Savage, J. Controlling non-additional credits from nutrient management in water quality trading programs through eligibility baseline stringency. Ecol. Econ. 2014, 105, 233-239. [CrossRef]

197. Jaung, W.; Bull, G.Q.; Kozak, R.; Elliott, C. Bundling forest ecosystem services for FSC certification: An analysis of stakeholder adaptability. Int. For. Rev. 2016, 18, 452-463. [CrossRef]

198. Yu, B.; Xu, L. Review of ecological compensation in hydropower development. Renew. Sustain. Energy Rev. 2016, 55, 729-738. [CrossRef]

199. Kuusela, O.P.; Amacher, G.S. A review of performance bonding in forest policy settings. Curr. For. Rep. 2016, 2, 189-200. [CrossRef] 
200. Reed, M.S.; Allen, K.; Attlee, A.; Dougill, A.J.; Evans, K.L.; Kenter, J.O.; Hoy, J.; McNab, D.; Stead, S.M.; Twyman, C.; et al. A place-based approach to payments for ecosystem services. Glob. Environ. Chang. 2017, 43, 92-106. [CrossRef]

201. Sun, J.; Dang, Z.; Zheng, S. Development of payment standards for ecosystem services in the largest interbasin water transfer projects in the world. Agric. Water Manag. 2017, 182, 158-164. [CrossRef]

202. Leimona, B.; Carrasco, L.R. Auction winning, social dynamics and non-compliance in a payment for ecosystem services scheme in Indonesia. Land Use Policy 2017, 63, 632-644. [CrossRef]

203. Choi, I.C.; Shin, H.J.; Nguyen, T.T.; Tenhunen, J. Water policy reforms in South Korea: A historical review and ongoing challenges for sustainable water governance and management. Water 2017, 9, 717. [CrossRef]

204. Guo, Z.; Xiao, X.; Li, D. An assessment of ecosystem services: Water flow regulation and hydroelectric power production. Ecol. Appl. 2000, 10, 925-936. [CrossRef]

205. Herrador, D.; Dimas, L. Payment for environmental services in El Salvador. Int. Mt. Soc. 2000, 20, $306-309$. [CrossRef]

206. Robertson, M.M. Emerging ecosystem service markets: Trends in a decade of entrepreneurial wetland banking. Front. Ecol. Environ. 2006, 4, 297-302. [CrossRef]

207. Asquith, N.M.; Vargas, M.T.; Wunder, S. Selling two environmental services: In-kind payments for bird habitat and watershed protection in Los Negros, Bolivia. Ecol. Econ. 2008, 65, 675-684. [CrossRef]

208. Dargusch, P.; Griffiths, A. Introduction to special issue: A typology of environmental markets. Australas. J. Environ. Manag. 2008, 15, 70-75. [CrossRef]

209. Chandrakanth, M.G.; Nagaraja, M.G. Payment for ecosystem services for water-Case of Cauvery. Curr. Sci. 2014, 107, 67-68.

210. Cooper, B.; Crase, L.; Pawsey, N. Best practice pricing principles and the politics of water pricing. Agric. Water Manag. 2014, 145, 92-97. [CrossRef]

211. Lentz, A.H.; Ando, A.W.; Brozović, N. Water quality trading with lumpy investments, credit stacking, and ancillary benefits. J. Am. Water Resour. Assoc. 2014, 50, 83-100. [CrossRef]

212. Balana, B.B.; Yatich, T.; Mäkelä, M. A conjoint analysis of landholder preferences for reward-based land-management contracts in Kapingazi watershed, Eastern Mount Kenya. J. Environ. Manag. 2011, 92, 2634-2646. [CrossRef]

213. Filipe,J.M.; Moreira, C.L.; Bessa, R.J.; Silva, B.A. Optimization of the variable speed pump storage participation in frequency restoration reserve market. In Proceedings of the 13th International Conference on the European Energy Market (EEM), Porto, Portugal, 6-9 June 2016; pp. 1-6.

214. Xu, M.; Li, C.; Shen, N.; Cai, Y.; Wang, X. Eco-compensation analyses for Drinking Water Reserves based on integrated ecosystem health assessment. J. Environ. Account. Manag. 2016, 4, 115-127. [CrossRef]

215. Zhao, L.; Huang, W.; Gao, H.O.; Xue, J.; Li, C.; Hu, Y. A cooperative approach to reduce water pollution abatement cost in an interjurisdictional lake basin. J. Am. Water Resour. Assoc. 2014, 50, 777-790. [CrossRef]

216. Guillozet, K. Shade trading: An emerging riparian forest-based payment for ecosystem services market in Oregon, USA. Environ. Manag. 2015, 56, 957-970. [CrossRef] [PubMed]

(C) 2020 by the authors. Licensee MDPI, Basel, Switzerland. This article is an open access article distributed under the terms and conditions of the Creative Commons Attribution (CC BY) license (http://creativecommons.org/licenses/by/4.0/). 